\title{
SCIENTIFIC REPORTS

\section{Signatures of Molecular Unification and Progressive Oxidation Unfold in Dissolved Organic Matter of the Ob-Irtysh River System along Its Path to the Arctic Ocean}

\author{
I. V. Perminova ${ }^{1 *}$, E. A. Shirshin ${ }^{2}$, A. Zherebker ${ }^{1,3}$, I. I. Pipko ${ }^{4,6}$, S. P. Pugach ${ }^{4,6}$, O. V. Dudarev ${ }^{4,6}$, \\ E. N. Nikolaev ${ }^{3}$, A. S. Grigoryev ${ }^{3,5}$, N. Shakhova ${ }^{6,7}$ \& I. P. Semiletov ${ }^{4,6,8}$
}

The Ob-Irtysh River system is the seventh-longest one in the world. Unlike the other Great Siberian rivers, it is only slightly impacted by the continuous permafrost in its low flow. Instead, it drains the Great Vasyugan mire, which is the world largest swamp, and receives huge load of the Irtysh waters which drain the populated lowlands of the East Siberian Plain. The central challenge of this paper is to understand the processes responsible for molecular transformations of natural organic matter (NOM) in the ObIrtysh river system along the South-North transect. For solving this task, the NOM was isolated from the water samples collected along the $3,000 \mathrm{~km}$ transect using solid-phase extraction. The NOM samples were further analyzed using high resolution mass spectrometry and optical spectroscopy. The obtained results have shown a distinct trend both in molecular composition and diversity of the NOM along the South-North transect: the largest diversity was observed in the Southern "swamp-wetland" stations. The samples were dominated with humic and lignin-like components, and enriched with aminosugars. After the Irtysh confluence, the molecular nature of NOM has changed drastically: it became much more oxidized and enriched with heterocyclic N-containing compounds. These molecular features are very different from the aliphatics-rich permafrost NOM. They witnesses much more conservative nature of the NOM discharged into the Arctic by the Ob-Irtysh river system. In general, drastic reduction in molecular diversity was observed in the northern stations located in the lower Ob flow.

Arctic ecosystems are most vulnerable both to global climate change and to its consequences. This is a region, which stores up to $50 \%$ of the global soil organic carbon $(\mathrm{C})^{1}$. According to the reported estimates ${ }^{2}$, the permafrost carbon accounts for $1300 \mathrm{Pg}$, whereas the non-permafrost carbon - only $500 \mathrm{Pg}$. The freshwater ecosystems are important contributors into the global carbon cycle. They are rich in natural organic matter (NOM), which transforms along its transport in the fluvial systems from the land to the ocean ${ }^{3-6}$. Arctic rivers are the major receivers of the organic carbon released due to permafrost thaw, which increases substantially their role in the global flux of terrestrial carbon ${ }^{7-26}$. The rivers transport approximately $34 \mathrm{Tg} \mathrm{yr}^{-1}$ of dissolved organic carbon (DOC) and discharge it into the Arctic Ocean ${ }^{27}$

The Ob-Irtysh river system is the seventh-longest one in the world. It is the westernmost of the three Great Siberian rivers: Yenisei, Lena, and Ob. It flows into the Arctic Ocean via the Kara Sea and contributes, on average, $427 \mathrm{~km}^{3}$ freshwater per year. This accounts for $15 \%$ of the total freshwater flow into the Arctic Ocean, which

\footnotetext{
${ }^{1}$ Department of Chemistry, Lomonosov Moscow State University, Leninskie Gory 1-3, Moscow, 119991, Russia. ${ }^{2}$ Department of Physics, Lomonosov Moscow State University, Leninskie Gory 1-2, Moscow, 119991, Russia. ${ }^{3}$ Skolkovo Institute of Science and Technology, 143025, Skolkovo, Moscow region, Russia. ${ }^{4} \mathrm{~V} . I$. II'ichev Pacific Oceanological Institute, Russian Academy of Sciences, Vladivostok, 690041, Russia. ${ }^{5}$ Kharkevich Institute for Information Transmission Problems, Russian Academy of Sciences, Bolshoy Karetny per. 19, build.1, Moscow, 127051, Russia. ${ }^{6}$ National Research Tomsk Polytechnic University, Tomsk, 634050, Russia. ${ }^{7}$ International Arctic Research Center, University of Alaska Fairbanks, Fairbanks, AK, 99775, USA. ${ }^{8}$ Moscow Institute of Physics and Technology, 9 Institutskiy per., Dolgoprudny, Moscow Region, 141701, Russia. *email: iperm@org.chem.msu.ru
} 
empties a huge load of DOC into the Arctic ${ }^{28,29}$. Unlike the other Siberian rivers (e.g., Lena, Kolyma), the basin of the Ob-Irtysh river system is only slightly impacted by the continuous permafrost: the permafrost exists only in the northern part of the Ob River watershed and occupies less than 5\% of its whole area. Instead, the Ob tributaries drain the Great Vasyugan mire, which is the largest swamp system in the northern hemisphere. It is located in the central sector of the West Siberian plain ${ }^{28,29}$. The area of the Great Vasyugan Mire is over $55000 \mathrm{~m}^{2}$, which is about $2 \%$ of the whole area of peat bogs of the world ${ }^{30}$. In the low flow, the Ob River receives a huge load of the Irtysh waters, which drain the lowlands of the East Siberian Plain ${ }^{31}$. Swampiness of the basin between the Irtysh and the $\mathrm{Ob}$ rivers reaches $50-80 \%{ }^{32}$. The Irtysh is as long as the Ob River before its confluence. It starts in China, flows via Mongolia, Kazakhstan, South Russia, before it finally meets the Ob River ${ }^{31}$. Due to the size and length of the Irtysh river, its confluence transforms the Ob river into the Ob-Irtysh river system. This makes the study of molecular components of the NOM in the $\mathrm{Ob}$ - Irtysh river system of particular importance for understanding evolution of the Arctic ecosystems under conditions of global climate change.

NOM is comprised of extremely heterogeneous mixture of organic compounds ${ }^{33}$. This is why the molecular studies of NOM need a use of high resolution techniques, such as Fourier transform ion cyclotron resonance mass spectrometry (FTICR MS) ${ }^{34}$. FTICR MS in combination with soft ionization techniques is capable of identifying tens of thousands of individual molecular ions in humic substances and $\mathrm{NOM}^{35,36}$. This method has become a state of the art technique for analysis of evolution of molecular composition of NOM and for revealing the roots of its persistence in the environment ${ }^{37}$. A whole number of papers have been recently published on molecular compositions of the NOM of the largest rivers in the world including both the Amazon and Congo rivers as well as the great Siberian rivers (e.g., Lena, Yenisei, Kolyma, North Dvina ${ }^{24,38-40}$. Still, we could not find a single dataset on molecular analysis of NOM in the Ob-Irtysh river system and its tributaries. We believe that this study might fill in this gap and provide the missing data on molecular fingerprints of the $\mathrm{Ob}$ - Irtysh river basin, which drains the largest swamp in the world - the Great Vasyugan Mire, and stretches over the multiple climatic zones.

The main objective of this study was to assess transformation of molecular composition of NOM along the $3,000 \mathrm{~km}$ transect of the Ob-Irtysh river system from the Ob Bay (Kara Sea) up to its confluence with the Tom? We used FTICR MS, fluorescence and UV/Vis spectroscopy for the analysis of NOM. The obtained data were statistically analyzed to reveal the relationships between molecular composition of NOM and the bulk hydrochemistry parameters of the transect under study.

\section{Experimental Section}

Study area. The Ob-Irtysh basin encompasses several climatic zones and includes different natural environments (Fig. 1). The Northern part of the basin is impacted by the presence of permafrost, which is continuous in the Far North, and it is sporadic in the middle flow ${ }^{41,42}$. Another significant feature of the Ob Basin is the presence of the biggest mire system - Vasyugan Mire, located in the region of sporadic and isolated permafrost ${ }^{41}$. The third remarkable feature is a huge impact of the Irtysh River, which is regarded as a part of the main course rather than as the Ob's major tributary: in length it is longer than the Ob River ${ }^{43,4}$. The confluence of Irtysh transforms the low flow of the $\mathrm{Ob}$ River, which was of particular interest for this expedition, into the Ob-Irtysh river system. All three features are important for understanding the transformation pattern of NOM in the fluvial system of the Ob-Irtysh.

The sampling was conducted from July 7 to 23, 2016, along the 2,952 km North - South transect in the mainstream of the $\mathrm{Ob}$ River. The sampling started in the $\mathrm{Ob}$ Bay and continued southbound of the Salekhard city up to the Tomsk city aboard the vessel "OM-341" (Fig. 1). The ship was moving from North to South, - and the stations numbering followed the ship route: it increased from North to South. This direction is opposite to the geographical flow of the Ob River, which flows from South to North. The study was carried out using a hydrological conductivity-temperature-depth (CTD) SBE 19plus SEACAT Profiler probe (www.seabird.com) equipped with fluorescence, dissolved oxygen, and turbidity sensors. Water samples for determination of hydrochemical and hydrooptical parameters were collected from the surface and bottom horizons using PVC batometers of Niskin system.

Sampling and determination of hydrochemistry parameters. The $1-3 \mathrm{~L}$ seawater samples were vacuum-filtered onboard through $25 \mathrm{~mm}$ diameter pre-combusted borosilicate glass fiber filters (Whatman GF/F, $0.7 \mu \mathrm{m}$ cut-off) using all-glass filtration system. The samples were stored in $60 \mathrm{~mL}$ Nalgene high-density polyethylene bottles. The filtered samples were stored in the refrigerator for a maximum of 4 weeks before the analyses for DOC. DOC was analyzed via high-temperature catalytic oxidation using the Shimadzu TOC-VCPH system ${ }^{45}$. Inorganic carbon was removed by acidifying the samples to $\mathrm{pH} 2$ with $2 \mathrm{M} \mathrm{HCl}$ and sparging for 8 min prior to analysis. All procedures for calibration and data analysis followed Sharp et al ${ }^{46}$.

$\mathrm{pH}$ was measured on board using potentiometric technique ${ }^{47}$ on the NBS scale using a combined electrode calibrated against HANNA buffer solutions ( $\mathrm{pH} 4.00,7.03,9.22$ at $\left.20^{\circ} \mathrm{C}\right)$. Accuracy of $\mathrm{pH}$ measurements was $0.02 \mathrm{pH}$ units. Total alkalinity $\left(\mathrm{A}_{\mathrm{T}}\right)$ was determined on board using titration technique: a sample of $25 \mathrm{~mL}$ of water was titrated with $0.02 \mathrm{M} \mathrm{HCl}$ in an open cell according to Dickson and Goyet ${ }^{47}$, Bruevich ${ }^{48}$, Pavlova et al ${ }^{49}$. All measurements were performed at $(20.0 \pm 0.1)^{\circ} \mathrm{C}$. $\mathrm{A}_{\mathrm{T}}$ measurements were performed with a precision of $3 \mu \mathrm{mol}$ $\mathrm{kg}^{-1}$. Exact concentration of $\mathrm{HCl}$ for alkalinity determination was found using titration with a standard solution of $\mathrm{Na}_{2} \mathrm{CO}_{3}$ prepared by a weight of $\mathrm{Na}_{2} \mathrm{CO}_{3}$ of $99.995 \%$ purity ${ }^{47,49}$. Absorbance of CDOM was measured using a UNICO 2804 spectrophotometer equipped with a $1 \mathrm{~cm}$ quartz cuvette onboard the vessel. The readings were taken from 200 to $600 \mathrm{~nm}$ at $1 \mathrm{~nm}$ intervals. Milli-Q (Millipore) water was used as a reference for all samples. Prior to analysis the water samples were discharged through acid-washed Whatman glass fiber filters (GF/F, pore size $0.7 \mu \mathrm{m})$. The absorption coefficient $\left(a_{\lambda}, \mathrm{m}^{-1}\right)$ was calculated as follows:

$$
a_{\lambda}=2.303 \mathrm{~A}_{\lambda} / \mathrm{L},
$$




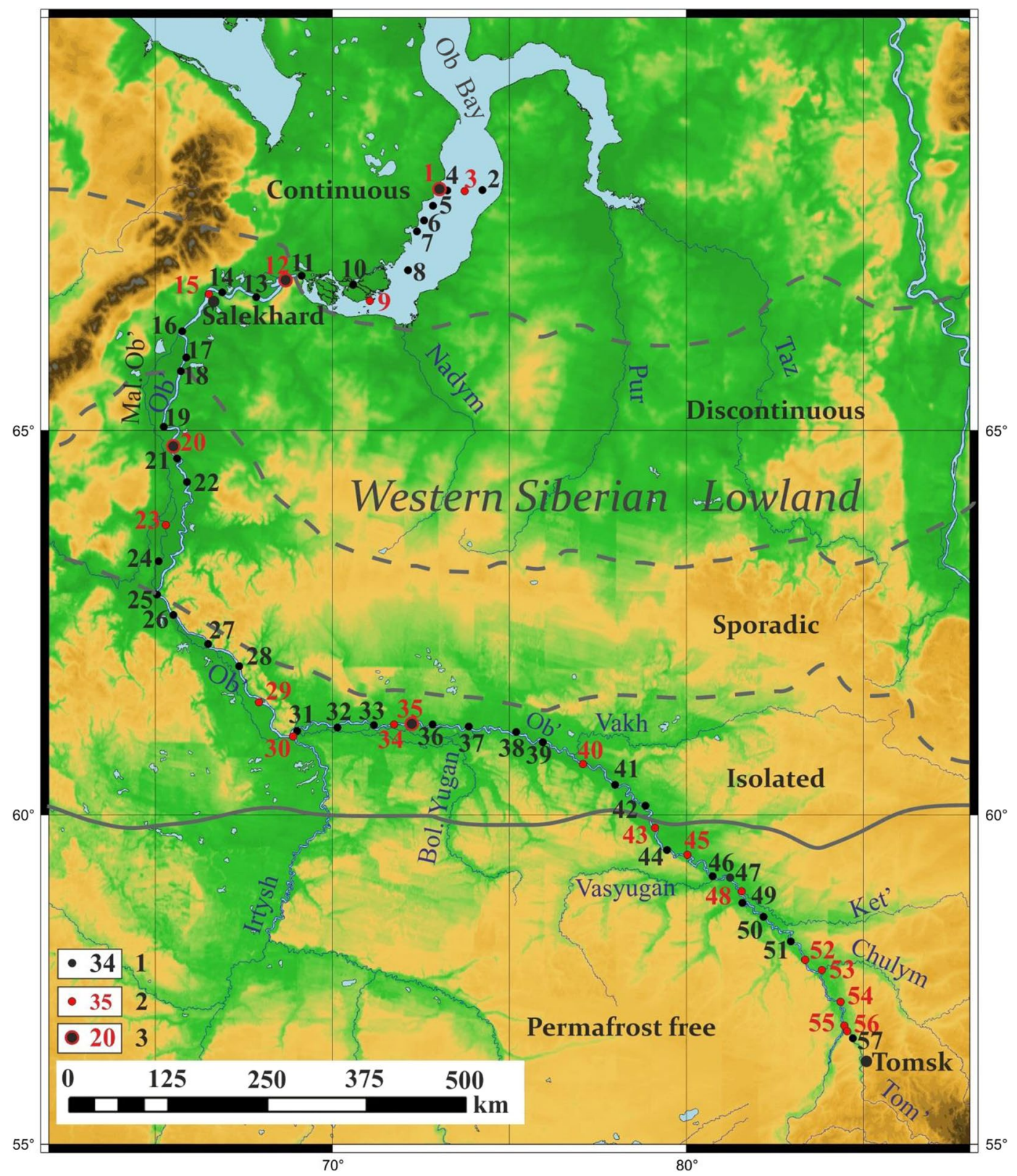

Figure 1. The map of sampling region and the station locations for interdisciplinary studies along the Ob-Irtysh river system. The complex stations are designated by dots highlighted in black color, the stations sampled additionally for the FTICR MS studies are designated by dots highlighted in red color, coastal stations are designated by dots circumvented with red color and shown by red numbers. The dashed lines mark boundaries of the permafrost zones, the solid line marks boundary between the permafrost zone and permafrost-free area. The major flow direction of the Ob-Irtysh river system is from South to North. The map was created using the open source GMT 5 software, Version 5.4 .5 https://www.generic-mapping-tools.org/, (Wessel et al.) $)^{72}$.

where $A_{\lambda}$ is optical density at the wavelength $\lambda$, and $\mathrm{L}$ is the cell path length expressed in meters. The dependence of $a_{\lambda}$ on $\lambda$ is described using Eq. (2):

$$
a_{\lambda}=a_{\lambda 0} \exp \left\{-S\left(\lambda-\lambda_{0}\right)\right\},
$$

where $a_{\lambda 0}$ is the absorption coefficient at a reference wavelength $\lambda_{0}$, and $S$ is a slope of absorbance spectrum in logarithmic coordinates ${ }^{50}$.

The concentration of dissolved Si was determined colorimetrically (molybdate blue method) with an uncertainty of $1 \%$ using a Technicon automated analyzer. The partial pressure of $\mathrm{CO}_{2}$ in river water $\left(\mathrm{pCO}_{2}\right)$ was calculated from the values of $\mathrm{pH}$ and $\mathrm{A}_{\mathrm{T}}$ as described by Lewis and Wallace ${ }^{51}$. The details on the techniques used for determination of hydrochemistry parameters can be found elsewhere ${ }^{52-54}$. Twenty out of fifty-six samples collected were further used for determination of optical parameters using UV-Vis and fluorescence spectroscopy and for FTICR MS analysis. A list of these samples is given in Table 1. 


\begin{tabular}{|c|c|c|c|c|c|}
\hline Station \# & Code & Latitude $\left({ }^{\circ} \mathrm{N}\right)$ & Longitude $\left({ }^{\circ} \mathrm{E}\right)$ & Depth, m & Tributaries \\
\hline 1 & St-1 & 64.709 & 72.904 & Coastal zone & $\begin{array}{l}\text { the Ob Bay, small } \\
\text { stream }\end{array}$ \\
\hline 3 & St-3 & 67.70876 & 73.74125 & 8 & the Ob Bay \\
\hline 9 & St-9 & 66.50481 & 71.06277 & 4.2 & the Ob Bay \\
\hline 12 & St-12 & 66.769 & 68.948 & Coastal zone & \\
\hline 15 & St-15 & 66.57932 & 66.51943 & 7 & the Polui River \\
\hline 20 & St-20 & 65.059 & 65.272 & Coastal zone & $\begin{array}{l}\text { small lake in the } \\
\text { floodplain }\end{array}$ \\
\hline 23 & St-23 & 63.84697 & 65.30216 & 9 & the Malaya Ob River \\
\hline 29 & St-29 & 61.55264 & 67.93597 & 14 & \\
\hline 30 & St-30 & 61.08942 & 68.89404 & 11.5 & the Irtysh River \\
\hline 34 & St-34 & 61.2534 & 71.7499 & 9 & \\
\hline 35 & St-35 & 61.281 & 72.380 & Coastal zone & \\
\hline 40 & St-40 & 60.71129 & 77.08165 & 9.5 & \\
\hline 43 & St-43 & 59.81291 & 79.10876 & 17 & \\
\hline 45 & St-45 & 59.43168 & 80.02385 & 17.5 & the Tym River \\
\hline 48 & St-48 & 58.89939 & 81.55622 & 11 & the Ket' River \\
\hline 52 & St-52 & 57.88217 & 83.34609 & 14.5 & \\
\hline 53 & St-53 & 57.73065 & 83.82073 & 12 & the Chulym River \\
\hline 54 & St-54 & 57.24546 & 84.35075 & 12 & \\
\hline 55 & St-55 & 56.87877 & 84.45362 & 6 & \\
\hline 56 & St-56 & 56.79613 & 84.53154 & 8 & the Tom' River \\
\hline
\end{tabular}

Table 1. A list of the water samples of the Ob River used for molecular analysis of DOM.

Isolation of DOM. Solid-phase extraction (SPE) of DOM from the water samples was conducted using the Bond Elut PPL cartridges (Agilent) according to the published protocol ${ }^{55}$. An SPE PPL cartridge $(1 \mathrm{~g}, 6 \mathrm{~mL}) \mathrm{was}$ activated by $6 \mathrm{~mL}$ of methanol prior to extraction. A water sample $(50 \mathrm{~mL})$ was acidified to $\mathrm{pH} 2$ and passed through the activated cartridge at the flow rate of $10 \mathrm{~mL} \cdot \mathrm{min}^{-1}$. Then, a volume of $6 \mathrm{~mL}$ of $0.01 \mathrm{M} \mathrm{HCl}$ was passed through the cartridge loaded with DOM material for salt removal, and the cartridge was dried by blowing nitrogen for $10 \mathrm{~min}$. The adsorbed DOM was eluted by $6 \mathrm{~mL}$ of methanol at a flow rate of $2 \mathrm{~mL} \cdot \mathrm{min}^{-1}$. The eluted solutions were kept in the freezer at $-30{ }^{\circ} \mathrm{C}$ until FTICR MS analysis. In total, 20 DOM samples were obtained using the described technique.

FTICR MS measurements and data treatment. FTICR MS analysis of the isolated DOM samples was performed using an FT MS spectrometer Apex Ultra (Bruker Daltonics) equipped with a dynamically harmonized cell, a $7 \mathrm{~T}$ superconducting magnet, and an electrospray ionization (ESI) source. The spectrometer is located at the Orekhovich Institute of Biomedical Chemistry of RAMS (Moscow, Russia). Mass-spectra were acquired in negative ionization mode by direct infusion at a flow rate of $120 \mathrm{~mL} \cdot \mathrm{h}^{-1}$ by summarizing $400 \mathrm{scans}$. Internal calibration of the obtained mass-spectra was systematically conducted using the known peak series of DOM reaching accuracy values of $<0.5 \mathrm{ppm}$. Mass-lists were composed of peaks with signal to nose ratio $(\mathrm{S} / \mathrm{N})>6 \mathrm{using}$ Data Analysis software (Bruker Daltonics, USA). Molecular compositions were assigned using in house-made Transhumus software. Ion charge was determined for the most abundant peaks and extended for minor peaks using total mass differences algorithm ${ }^{56}$. The assigned formulae were filtered following the typical atomic constrains for DOM: $\mathrm{O} / \mathrm{C} \leq 1, \mathrm{H} / \mathrm{C} \leq 2, \mathrm{C} \leq 120, \mathrm{H} \leq 200,0<\mathrm{O} \leq 60, \mathrm{~N} \leq 2, \mathrm{~S} \leq 1$.

The formulae were classified into classes of chemical compounds according to their stoichiometries as described by Kellerman et al. ${ }^{57}$ : aliphatics $(0<\mathrm{O} / \mathrm{C}<0.65,1.6 \leq \mathrm{H} / \mathrm{C}<2.2)$, N-saturated (peptides and amino-sugars, $1 \leq \mathrm{N}, 0.1 \leq \mathrm{O} / \mathrm{C}<0.65,1 \leq \mathrm{H} / \mathrm{C}<2.2)$, low-oxidized lignins $(0.1 \leq \mathrm{O} / \mathrm{C}<0.5,0.7 \leq \mathrm{H} / \mathrm{C}<1.6)$, oxidized lignins $(0.5 \leq \mathrm{O} / \mathrm{C}<1,0.7 \leq \mathrm{H} / \mathrm{C}<1.6)$, condensed tannins $(0<\mathrm{O} / \mathrm{C}<0.5,0.3 \leq \mathrm{H} / \mathrm{C}<0.7)$, hydrolysable tannins $(0.5 \leq \mathrm{O} / \mathrm{C}<1,0.3 \leq \mathrm{H} / \mathrm{C}<0.7)$, carbohydrates $(0.65 \leq \mathrm{O} / \mathrm{C}<1,1.3 \leq \mathrm{H} / \mathrm{C}<2.2)$. Intensity-weighted population density was calculated based on summarized relative intensity in each class as described by Perminova ${ }^{58}$ :

$$
D_{k}=\frac{\sum_{k=1}^{N_{i}} I_{i}}{\sum_{j=1}^{N} I_{j}}, k=1,2, \ldots n,
$$

where $D_{k}$ - contribution of molecular class in total intensity, $\sum I_{i}-$ summarized relative intensity of each molecular class, $\sum \mathrm{I}_{\mathrm{j}}$ - total relative intensity of all molecules.

Double bond equivalent (DBE) was calculated according to the following equation:

$$
\mathrm{DBE}=\mathrm{C}+1-[(\mathrm{H}-\mathrm{N}-\mathrm{P}) / 2]
$$


Analysis of optical properties. Optical measurements were performed on 20 water samples prior to DOM extraction. The corresponding water samples were stored in the dark at $4{ }^{\circ} \mathrm{C}$. Absorption measurements were performed on a Lambda-25 spectrophotometer (Perkin-Elmer, USA). For the absorption spectra, the ratio of two slopes $\left(\mathrm{S}_{\mathrm{r}}\right)$ was calculated by estimating the spectral regions of $275-295 \mathrm{~nm}$ and $350-400 \mathrm{~nm}$, respectively, as described by Helms et al. ${ }^{59}$ The $\mathrm{S}_{\mathrm{r}}$ value is inversely proportional to molecular weight of DOM: the higher $\mathrm{S}_{\mathrm{r}}$ values might be indicative of the lower values of molecular weight.

The fluorescence measurements were performed on a FluoroMax-4 spectrofluorometer (Horiba, Japan). The fluorescence properties of the CDOM samples used in this study were examined with a use of both 1Dand 2D-fluorescence spectroscopy. 1D fluorescence spectra are easy to interpret and can be reliably described using fluorescence intensity ratio (FIR) approach. However, 1D fluorescence spectroscopy does not enable comprehensive analysis of complex fluorophore mixtures, such as molecular ensemble of CDOM. That is why two dimensional (2D) fluorescence spectroscopy became state-of-art technique for the analysis of $\mathrm{CDOM}^{60}$. The two-dimensional fluorescence spectra are measured by the systematic scanning of the excitation wavelength while the corresponding emission spectra are collected. The resulting two-dimensional excitation-emission matrix (EEM) enables identification of multiple fluorophores in the mixture. However, EEMs are much more demanding with regard to quantitative treatment. The most widely adopted approach to their treatment is decomposition of EEM into components using the PARAFAC modeling ${ }^{60}$. However, its major limitation is the size of the data set, - it works reliably only on the big data sets $(n>50)$. In our case, we had 20 samples at our disposal, which could be critical for the PARAFAC results. So, we opted to use both $1 \mathrm{D}$ and 2D fluorescence spectroscopy: the former was to enable simple description of the observed trends as well as validation of the latter - the PARAFAC-based conclusions.

1D fluorescence spectra were measured in the range of $280-410 \mathrm{~nm}$ excitation wavelengths with a step of $10 \mathrm{~nm}$, while the emission detection was performed in the range of 300-700 $\mathrm{nm}$. The spectral slit widths were set to $5 \mathrm{~nm}$. The maximum optical density at the excitation wavelength did not exceed 0.1 . The measured spectra were processed and excitation-emission matrices (EEMs) were built using the Python programming language. For the 1D fluorescence spectra, two descriptors were calculated. Firstly, an impact of the protein-like (tryptophan-like) fluorescence was assessed using the $\mathrm{F}_{350} / \mathrm{F}_{\max }$ fluorescence intensity ratio by relating the intensity of fluorescence at $350 \mathrm{~nm}\left(\mathrm{~F}_{350}\right)$ to the maximum fluorescence intensity $\left(\mathrm{F}_{\max }\right)$ at $280 \mathrm{~nm}$ excitation wavelength. The higher the $\mathrm{F}_{350} / \mathrm{F}_{\max }$ value is, the higher contribution of the protein-like fluorescence is. Secondly, the relative red shift of the fluorescence spectra was estimated with a use of the asymmetry ratio $\left(\mathrm{F}_{550} / \mathrm{F}_{375}\right)$. The asymmetry ratio was calculated by relating the fluorescence intensity measured at $550 \mathrm{~nm}$ and $375 \mathrm{~nm}$, respectively, at the $\lambda_{\text {ex }}=350 \mathrm{~nm}$. The higher asymmetry values might be indicative of the higher humification index of DOM, which is reflected in the larger contribution of oxidized aromatic moieties into molecular ensemble of $\mathrm{DOM}^{61}$.

The EEMs measured for all samples used in this study are presented in Fig. S1 (Supplementary Information, $\mathrm{SI})$. The PARAFAC modelling was performed using the staRdom package in $\mathrm{R}^{62}$. The PARAFAC model with three components turned out to be the most reliable. It yielded $\mathrm{R}^{2}$ similar to the models with the larger number of components. The latter indicated overfitting for an increased number of components. The calculated loadings for all components are given in Table $\mathrm{S} 1$ in the SI.

Statistical data treatment. The correlation patterns between molecular composition of the DOM samples used in this study and the hydrochemistry parameters were assessed using Spearman's rank correlation coefficient (Spearman correlation). The Spearman correlation was calculated for the hydrochemistry parameters and the sum-normalized intensity of FTICR MS peaks with unambiguous formulae assignment. The dataset included 18 samples, and the correlations were tested only for the common formulae, nominally, for the formulae found in all samples $(n=1629)$. Only significant Spearman rank correlation coefficients (P-value $<0.05)$ were considered. The results were plotted in the VK diagram only for the hydrochemistry parameters with $>200$ significant correlations with the sum-normalized intensity of peaks. The strongest direct correlations were highlighted in red $(\mathrm{R}>0.7)$ and the inverse correlations - in blue $(\mathrm{R}<-0.7)$.

\section{Results and Discussion}

Hydrochemistry and hydrooptics of the Ob-Irtysh river system in the region under study. The specific features of the $\mathrm{Ob}$ River catchment were discussed above under the site description. After the confluence with the major tributary - the Irtysh River, the length of the Ob-Irtysh River system accounts for $5410 \mathrm{~km}$. This makes it to the longest one in Russia. The average annual discharge of the Ob River is $427 \mathrm{~km}^{3}$, which is the third one in Russia after the Yenisei and the Lena ${ }^{43,44}$. The water sampling was performed in the middle Ob (from the junction with the Tom to the Irtysh confluence), and in the lower Ob (from the junction with the Irtysh to the Ob Bay) as it is shown in Fig. 1. The study area stretched across the different climatic zones including coalescence of the Ob River with several large tributaries: Tom', Chulym, Ket', Tym, Vasyugan, Malaya Ob, Poluy, and the largest one - the Irtysh River. They are listed in Table 1. Each tributary had its specific biogeochemical features associated with the landscape-geochemical characteristics of the drained areas; the signal of these waters could be traced in the mainstream of the $\mathrm{Ob}$ River. All hydrochemistry parameters are given in Fig. 2.

In the main riverbed, water temperature changed slightly (from 20.2 to $24.4^{\circ} \mathrm{C}$ ) with an average value of $22.7^{\circ} \mathrm{C}$. Small fluctuations were observed in the river mouth and in the confluence areas. The minimum water temperature for the study area accounted for $17.6^{\circ} \mathrm{C}$. It was measured in the Ob Bay (Fig. $2 \mathrm{~A}$ shows only the surface layer). The salinity values varied in a narrow range of $0.04-0.12 \mathrm{~g} \mathrm{~kg}^{-1}$ at an average value of $0.08 \mathrm{~g} \mathrm{~kg}^{-1}$ and decreased with an increase in latitude (Fig. 2B). Minimum salinity values were found in the Ob Bay, which could be caused by the passage of the flood wave and the presence of flood waters in the bay ${ }^{58}$. The measured and calculated parameters of the carbonate system revealed a pronounced latitudinal trend. The elevated values were observed for $\mathrm{pH}$ (Fig. 2C), bicarbonate concentration (Fig. 2D), and total alkalinity (Fig. 2E) in the Southern 

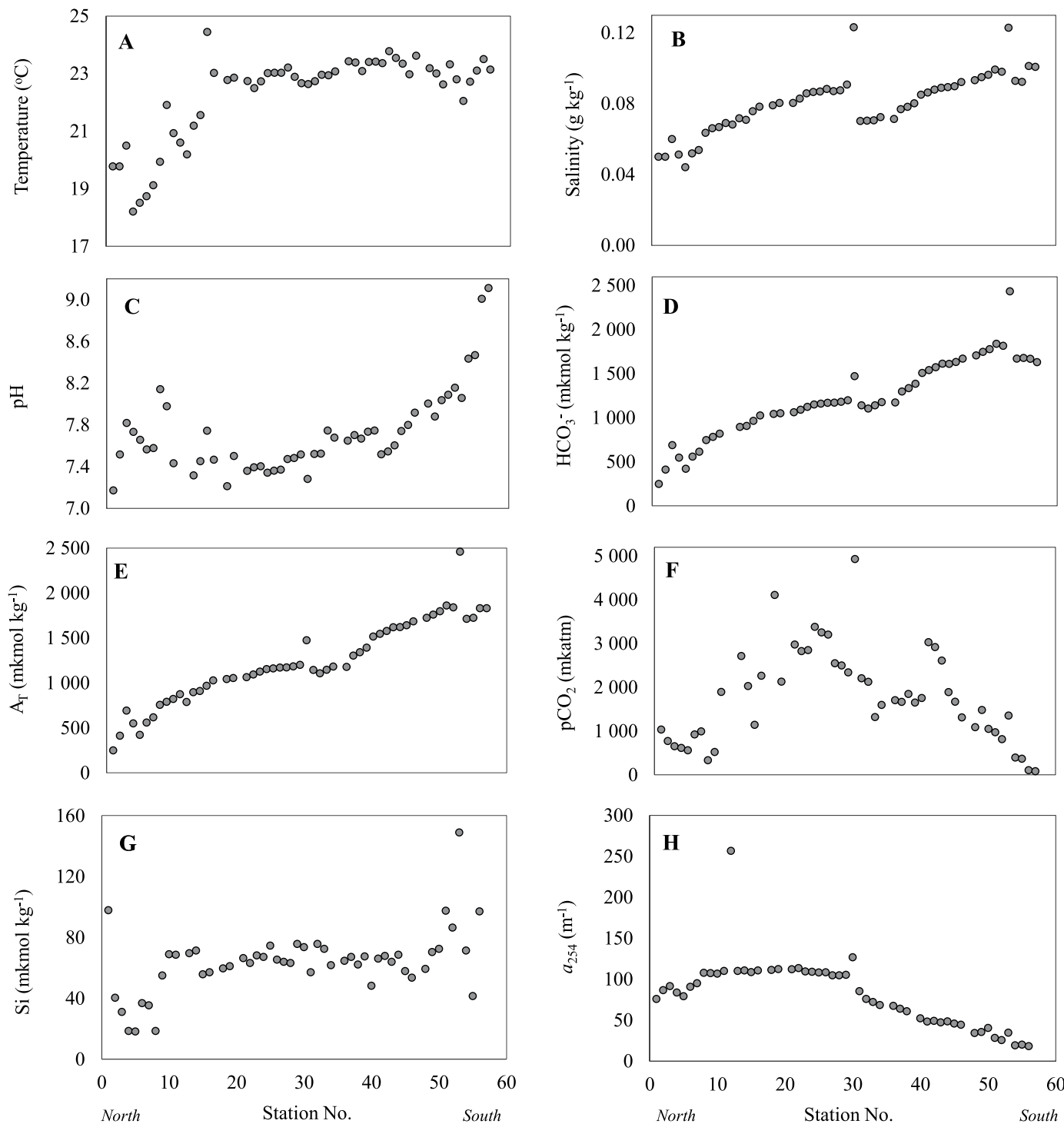

Figure 2. Hydrochemistry (A-G) and hydrooptics parameters $(\mathbf{H})$ measured in the surface waters of the ObIrtysh river system along the cruize route.

study area. The highest values were reached in the Tom' River and in the zone influenced by the Chulym River ${ }^{23}$. The spatial distribution of these parameters, on one side, followed the pattern of the permafrost area, and reflected an increase in groundwater supply in the drainage basin with a decrease in latitude ${ }^{41}$. On the other side, they were heavily impacted by the confluence with the Irtysh River (St. 30). This demarcation point (seen as an abrupt increase in almost all hydrochemistry parameters shown in Fig. 2) was designating transition from the middle $\mathrm{Ob}$ dominated by the drainage from the Vasyugan Mire to the lower Ob dominated by the Irtysh waters. This transition was clearly reflected in the dissolved $\mathrm{CO}_{2}$ concentrations (Fig. 2F). They reached minimum values in the South study area characterized with the maximum photosynthesis rates. These stations were also impacted by an increased contribution of groundwater. Much higher $\mathrm{CO}_{2}$ concentrations were observed after the Irtysh confluence, which could be connected to an intense inflow of waters loaded with high concentrations of organic matter and its high degradation rate. The drop in concentration of $\mathrm{CO}_{2}$ was observed in the northernmost range of the transect in accordance with a temperature gradient shown in Fig. 2A. The content of dissolved silicon (Fig. 2G) did not show specific spatial distribution: the largest values were measured at the confluence of the $\mathrm{Ob}$ and Chulym rivers, and the minimum concentrations were measured in the $\mathrm{Ob}$ Bay waters. This might be indicative of a relative steady-state reached in silicate weathering along the $\sim 3,000 \mathrm{~km}$ south-north transect, except for the Chulym River confluence.

The hydrooptics parameter used in this study (Fig. $2 \mathrm{H}$ ) also revealed remarkable latitudinal trend, which was similar to the discussed above components of the carbonate system. The absorption coefficient at $254 \mathrm{~nm}$ is characteristic of the colored fraction of DOM (CDOM). It has dropped a factor of six from North to South; the minimum values were obtained for the Tom' River. Given that the optical parameters of CDOM depend on its structural arrangement ${ }^{61}$, we have measured off-line full UV-Vis spectra and fluorescence spectra (Figs. 3 and 4, 

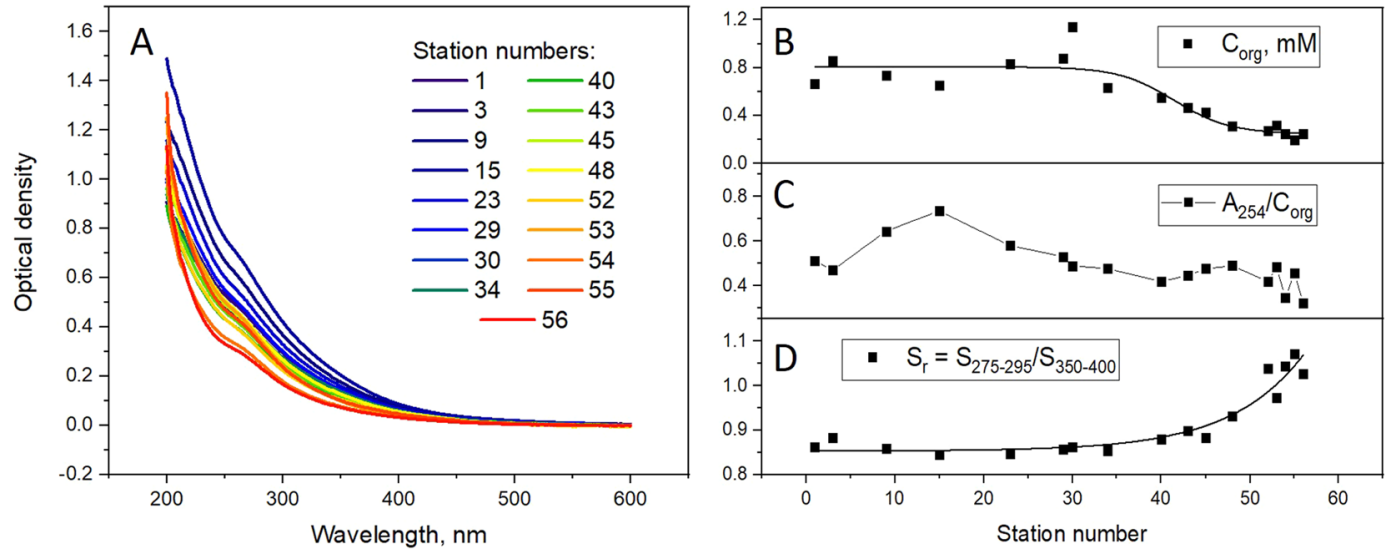

Figure 3. UV-Vis spectra of the surface water samples of the Ob River collected along the North-South transect (A), the dependence on the station number of the following parameters: the content of $\mathrm{C}_{\text {org }}, \mathrm{mM}(\mathrm{B})$; absorption at $254 \mathrm{~nm}$ normalized to the content of $\mathrm{C}_{\text {org }}$ (efficient extinction coefficient) (C); the ratio of the spectral slopes $\mathrm{S}_{\mathrm{r}}(\mathbf{D})$.
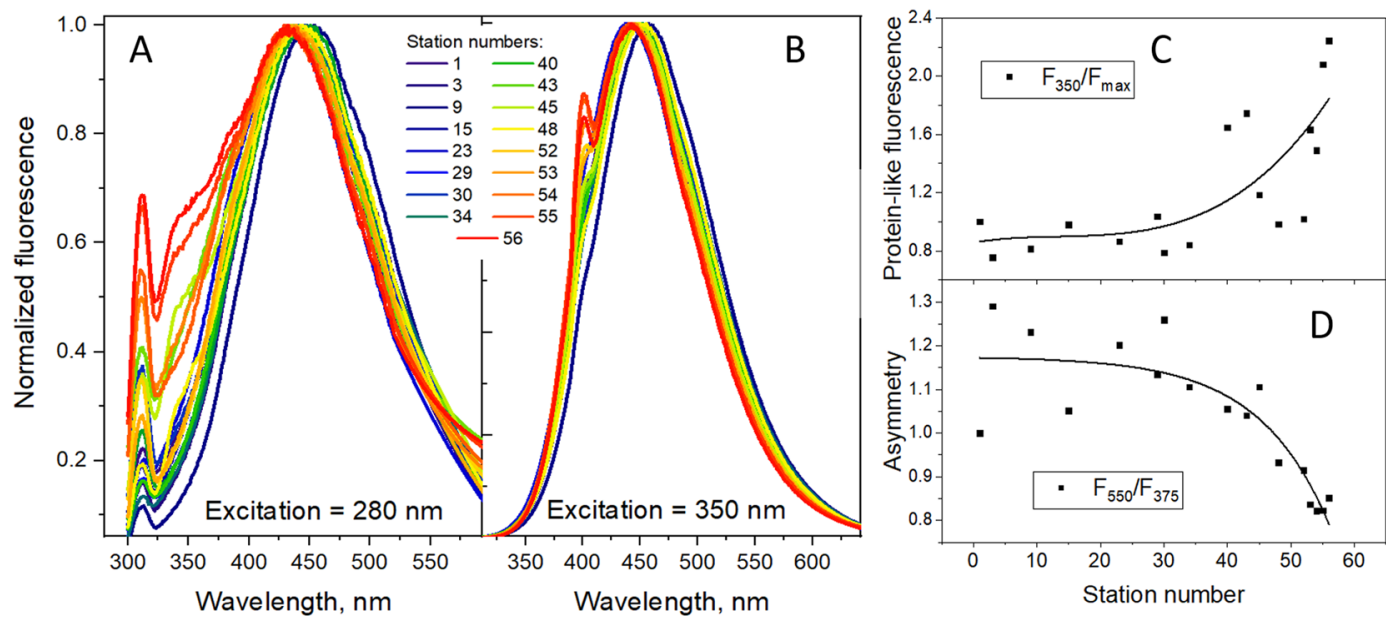

Figure 4. Fluorescence emission spectra of all CDOM samples used in this study obtained at 280 and $350 \mathrm{~nm}$ excitation wavelengths (A and $\mathbf{B}$, respectively). Dependence on the station number for the relative tryptophanlike fluorescence intensity $\left(\mathrm{F}_{350} / \mathrm{F}_{\max }\right)(\mathrm{C})$ and for the spectral band asymmetry $\left(\mathrm{F}_{350} / \mathrm{F}_{375}\right)(\mathrm{D})$.

respectively) for the representative set of water samples, which were further used for DOM isolation and molecular composition analysis.

From St. 30 and up North to the $\mathrm{Ob}$ Bay, we see high absorbance values: the corresponding absorbance spectra are highlighted in blue in Fig. 3A. The observed phenomenon might be connected mainly with a substantial increase in the content of $\mathrm{C}_{\text {org }}$ in the $\mathrm{Ob}$ River after the confluence with the Irtysh River, when it transforms into the Ob-Irtysh river system (Fig. 3B). We also observed a rise in the effective extinction coefficient (absorption at $254 \mathrm{~nm}$ normalized to $\mathrm{C}_{\text {org }}$ content), but to a lesser extent (Fig. 3C). The ratio of spectral slopes, $\mathrm{S}_{\mathrm{r}}$, is shown in Fig. 3D. It is characteristic of the DOM molecular weight. It can be seen that this value is almost constant from the $1^{\text {st }}$ to the $30^{\text {th }}$ station, and shows a gradual increase along with an increase in station numbers. This might be indicative of a decrease in the DOM molecular weight in the Southern stations. We note that the $\mathrm{S}_{\mathrm{r}}$ parameter is independent on concentration and, therefore, its concurrent variation with the $\mathrm{C}_{\text {org }}$ value is caused by two independent processes.

Normalized 1D-fluorescence emission spectra of the CDOM samples were measured at $280 \mathrm{~nm}$ and $350 \mathrm{~nm}$ excitation wavelengths and presented in Fig. 4A,B, respectively. The representative EEMs are shown in the SI. It can be clearly seen that the samples from the Southern stations are characterized by the substantial impact of protein-like (tryptophan-like, Trp) fluorescence, which is manifested in the low wavelengths region (Fig. 4A). This fact is illustrated in Fig. 4C. A gradual blue shift of the fluorescence spectra can be observed along with an increase in the station number (Fig. 4B,D), which might be indicative of a decrease in the content of oxidized aromatic moieties.

For the samples southbound from the station 40 (Fig. 1), the humic-like fluorescence dominates (Fig. 4C) that can be explained by a significant release of soil organic carbon into the Ob River in the region of the Great 

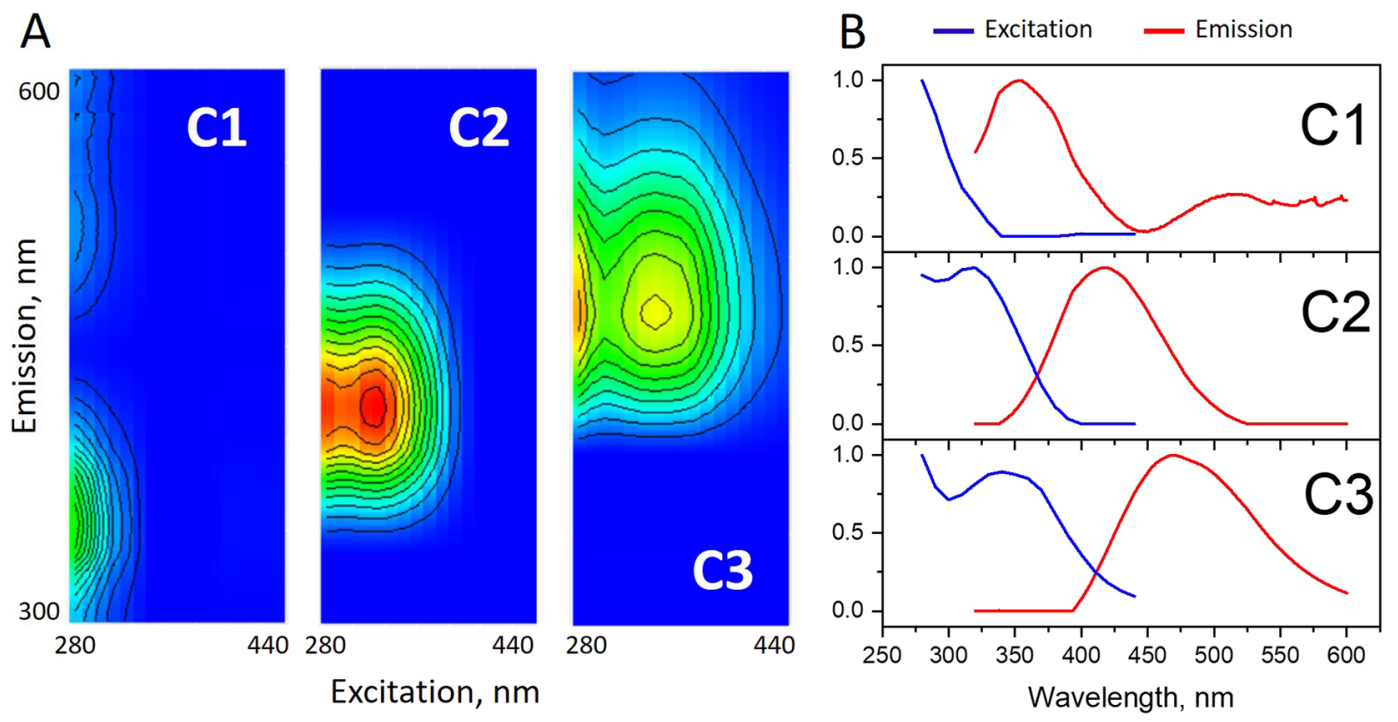

Figure 5. The three components of the PARAFAC deconvolution of the excitation-emission matrix (EEM) of the Ob CDOM dataset $(\mathrm{n}=20)$ used in this study represented as EEMs $(\mathbf{A})$ and excitation and emission $\operatorname{spectra}(\mathbf{B})$.

Vasyugan Mire $28,29,63$. These components represent allochthonous fluorophores, which occur in the river during seasonal cycles. They undergo microbial degradation and UV irradiation leading to secondary reactions of oxidation and condensation. Starting from the station 30 and further to the North, the protein-like fluorescence decreased, and the oxidized phenolic components prevailed over the humic-like fluorescence. Optical parameters (protein-like fluorescence and the ratio of humic-like and oxidized components fluorescence) showed direct correlation with hydrochemical parameters, namely, with the content of $C_{\mathrm{org}}(\mathrm{R}>0.8, \mathrm{p}<0.02)$.

The PARAFAC modelling for the Ob DOM data set (20 EEMs for the samples used in this study) yielded three components (Fig. 5A). They are close to the C350 (component 1), C410 (component 2), and C460 (component 3) species (Fig. 5B) described by Wuensch et al. ${ }^{64}$.

An overview of the $2 \mathrm{D}$ fluorescence data revealed the samples with very pronounced Trp-like fluorescence (component 1 ) in the South (St number $>40$ ). This contribution has been accounted for by the $\mathrm{F}_{350} / \mathrm{F}_{\max }$ ratio introduced for the analysis of the $1 \mathrm{D}$ spectra (Fig. 4C). We have calculated its impact into $2 \mathrm{D}$ spectra by a ratio of $\mathrm{C} 1 /(\mathrm{C} 2+\mathrm{C} 3)$. The dependence of the calculated ratio on the station number is shown in Fig. S2 in the SI: it followed the trend shown in Fig. 4C. This was expected while the peak $(\mathrm{ex}=280 / \mathrm{em}=350)$ makes the highest impact to the component 1 . The obtained data show consistency of $1 \mathrm{D}$ and $2 \mathrm{D}$ spectra with regard to quantitative assessment of the trend in the protein-like fluorescence species of the CDOM. The same was true for the red shift descriptors calculated from the respective loadings of the PARAFAC component: the ratio of the most red shifted component (component $3, \mathrm{ex}=350 / \mathrm{em}=470)$ and the more blue shifted component $2(\mathrm{ex}=320 / \mathrm{em}=420)$. We used the following ratios: $\mathrm{C} 2 / \mathrm{C} 1, \mathrm{C} 2 /(\mathrm{C} 1+\mathrm{C} 2)$, and $\mathrm{C} 2 /(\mathrm{C} 1+\mathrm{C} 2+\mathrm{C} 3)$. Their dependence on the station number (shown in Fig. S3 in the SI) exhibited a decrease for the stations southbound from St 35 ( $\mathrm{n}>35$ ) with more or less satisfactory quality. In general, the trends of the PARAFAC loadings followed the trend observed for the fluoresence intensity ratio $\left(\mathrm{F}_{550} / \mathrm{F}_{375}\right)$ ratio (Fig. $\left.4 \mathrm{D}\right)$, but with lesser quality. This can be caused by the impact of outliers.

Summarizing the conducted PARAFAC analysis, for the small dataset used in this study (20 samples), the fluorescence properties of CDOM could be described by 3 independent components and two descriptors composed of a combination of the PARAFAC loadings. These descriptors were related to the Trp-like fluorescence and to spectral asymmetry (the humification degree). The PARAFAC results turned out to be very similar to the 1D fluorescence spectra analysis. We understand that the fluorescence intensity ratio approach applied for the 1D spectra analysis implies substatial simplification: it does not take into account the components shapes. However, its application was sufficient for quantitative assessment of two independent trends in the CDOM composition (one purely protein-like and the other one - purely humic like). Its particular advantage is much lesser dependence on the size of the dataset and simplicity of the data treatment.

The observed trends are indicative of a gradual change in the molecular character of the DOM along the South-North transect of the Ob River: from more reduced, humic-like DOM until the confluence with the Irtysh River to much more oxidized DOM in the low part of the river bed, which could be a reflection of the molecular characteristics of the DOM prevailing in the Irtysh River. For elucidating the nature of molecular transformations in the quality of the DOM along the south-north transect of the Ob River, we have isolated DOM from 19 representative samples of the surface waters selected along the entire route of expedition in the various physical and geographical areas of the drainage basin (Table 1, Fig. 1) and characterized its molecular composition using FTICR MS. 


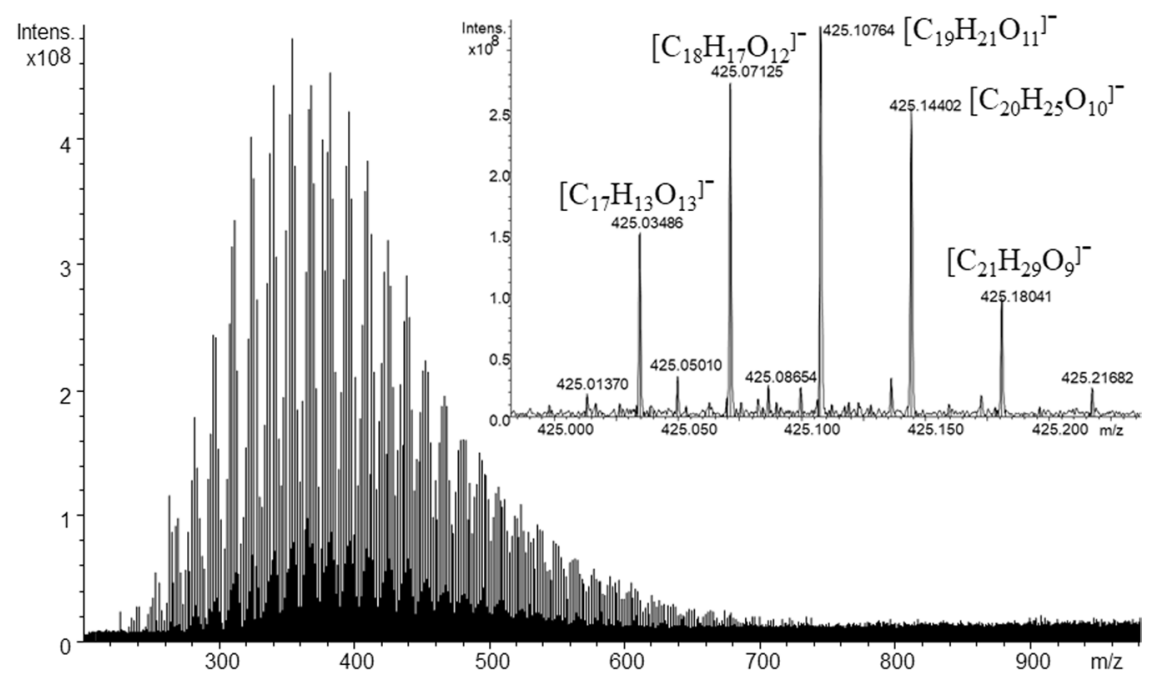

Figure 6. Typical FTICR mass-spectrum of the Ob River DOM. The inset shows a magnified fragment at the nominal mass of $425 \mathrm{Da}$ with the peak assignments for the dominant peaks.

\begin{tabular}{|c|c|c|c|c|c|c|c|c|}
\hline \multirow[b]{2}{*}{ Sample } & \multirow{2}{*}{$\begin{array}{l}\text { The number of } \\
\text { assigned formulae }\end{array}$} & \multicolumn{3}{|c|}{$\begin{array}{l}\text { Contribution into the total } \\
\text { number of assignments, } \%\end{array}$} & \multicolumn{4}{|c|}{ Number-averaged parameters } \\
\hline & & $\mathrm{CHO}$ & CHON & CHOSN & $\mathrm{M}_{\mathrm{n},}, \mathrm{Da}$ & $O / C_{n}$ & $\mathrm{H} / \mathrm{C}_{\mathrm{n}}$ & $\mathrm{DBE}_{\mathrm{n}}$ \\
\hline St-1 & 4651 & 85 & 7 & 8 & 454 & 0.56 & 1.04 & 9.9 \\
\hline St-3 & 3779 & 81 & 6 & 13 & 441 & 0.55 & 1.12 & 9.1 \\
\hline St-9 & 2434 & 90 & 5 & 5 & 417 & 0.58 & 1.06 & 9.9 \\
\hline St-12 & 1973 & 97 & 2 & 1 & 448 & 0.59 & 0.99 & 11.1 \\
\hline St-15 & 1942 & 92 & 4 & 4 & 434 & 0.57 & 1.04 & 9.5 \\
\hline St-20 & 5060 & 72 & 10 & 18 & 437 & 0.58 & 1.11 & 8.9 \\
\hline St-23 & 1129 & 95 & 1 & 4 & 444 & 0.62 & 0.98 & 11.1 \\
\hline St-29 & 3459 & 88 & 7 & 5 & 426 & 0.58 & 1.05 & 10.1 \\
\hline St-30 & 3090 & 87 & 6 & 7 & 432 & 0.58 & 1.05 & 9.3 \\
\hline St-34 & 3155 & 88 & 6 & 6 & 437 & 0.57 & 1.00 & 9.9 \\
\hline St-35 & 2221 & 88 & 7 & 5 & 416 & 0.56 & 1.07 & 9.8 \\
\hline St-40 & 3668 & 86 & 8 & 6 & 435 & 0.56 & 1.06 & 9.5 \\
\hline St-43 & 3285 & 88 & 8 & 4 & 428 & 0.56 & 1.09 & 9.9 \\
\hline St-45 & 3679 & 90 & 5 & 5 & 479 & 0.59 & 1.03 & 10.5 \\
\hline St-48 & 4172 & 85 & 9 & 6 & 442 & 0.57 & 1.06 & 9.6 \\
\hline St-53 & 4018 & 83 & 10 & 7 & 448 & 0.56 & 1.05 & 10 \\
\hline St-54 & 4531 & 85 & 9 & 6 & 462 & 0.55 & 1.06 & 10 \\
\hline St-55 & 4265 & 82 & 10 & 8 & 441 & 0.54 & 1.05 & 9.8 \\
\hline St-56 & 3718 & 82 & 9 & 9 & 436 & 0.54 & 1.10 & 9.2 \\
\hline
\end{tabular}

Table 2. Number-averaged parameters obtained from the FTICR MS data.

Molecular composition of the DOM samples used in this study as measured by FTICR MS. FTICR mass-spectra obtained for the DOM samples under study consisted of one to four thousands of singly-charged ions with the peak S/N ratio $>6$ within 200-800 Da mass window. Figure 6 shows a typical FTICR mass-spectrum including a magnified fragment for a nominal mass of $425 \mathrm{Da}$.

Table 2 shows the molecular characteristics obtained for all 19 samples: the total number of assigned formulae for each DOM sample, the contributions of different stoichiometris (CHO, CHON, CHONS) into the total number of stoichiometries, and the number-averaged parameters calculated from the obtained FTICR mass spectra. For all DOM samples used in this study, the CHO formulae represented the major molecular components (more than $80 \%$ of all assignments), which is typical for $\mathrm{DOM}^{65}$. The sample collected at St. 20 (the lake of the Ob River floodplain) was characterized with extremely large number of assignments (5060). It was further excluded from the data set as an outlier when performing correlation analysis.

The obtained FTICR MS data were further plotted in Van Krevelen diagrams, which represent a projection of molecular ensemble stoichiometries onto $\mathrm{H} / \mathrm{C}$ vs $\mathrm{O} / \mathrm{C}$ coordinates ${ }^{66}$. Fig. 7 shows the Van Krevelen diagrams, which are typical for the upper-, middle- and lower flow of the Ob DOM. 

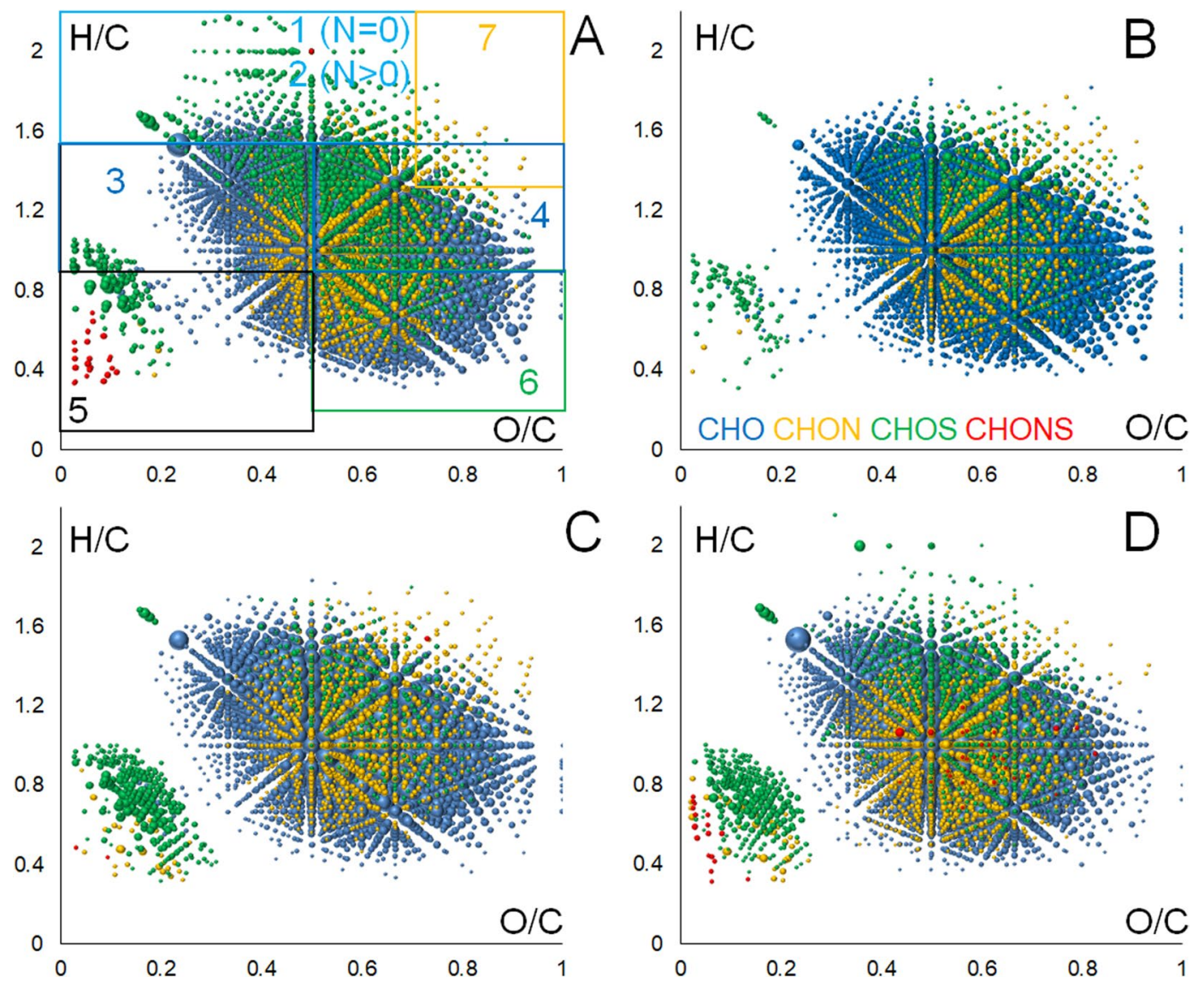

Figure 7. Van Krevelen diagrams for the Ob DOM samples: (A) St-1, (B) St-29, (C) St-40, (D) St-55. The formulae with $\mathrm{CHO}, \mathrm{CHON}, \mathrm{CHOS}$, and CHNOS compositions are highlighted with blue, orange, green, and red colors, respectively. Numerals 1-7 designate regions of aliphatic species, $\mathrm{N}$-containing saturated species (amino-sugars and peptides), low-oxidized and oxidized lignins, condensed tannins, hydrolyzable tannins and carbohydrates, respectively.

It can be deduced that the molecular profiles of the DOM samples used in this study were rather similar. The assigned formulae populated wide areas on the Van Krevelen diagrams from the relatively saturated reduced compounds $(\mathrm{H} / \mathrm{C} \sim 2)$ to the condensed oxidized ones $(\mathrm{H} / \mathrm{C}<0.4)$. However, the samples northbound from St. 30 (after the confluence with the Irtysh River) showed much lesser of the lignin-like compounds with $\mathrm{H} / \mathrm{C}>1.2$ and $\mathrm{O} / \mathrm{C}<0.5$. These samples were characterized with the maximum contribution of highly-oxidized aromatic compounds.

The specific feature of the most northern sample collected from the Ob Bay region (in a small stream flowing into the Ob Bay, St. 1) was a very significant contribution of the saturated CHOS components, which can be clearly seen as the multiple green dots in the Van Krevelen diagram (Fig. 7A). The middle-stream and upper-stream samples were characterized by the presence of mostly unsaturated and aromatic CHOS compounds. This could be attributed to intensive photochemical degradation under aerobic conditions leading to a cleavage of aromatic rings and formation of saturated compounds as it was shown for lignin-like DOM ${ }^{67}$.

For better visualization of the changes in molecular profiles of the DOM along the Ob-Irtysh river system flow from South to North, we have represented the Van Krevelen diagrams of each DOM sample under study as a superposition of the $\mathrm{CHO}$ (highlighted in blue) and the $\mathrm{CHON}$ (highlighted in red) formulae shown in the central panel of each triad of the VK diagrams in Fig. 8. Because of the low abundance of CHOS and CHONS compounds, we did not show them in these plots. Instead, we have displayed the subspace of common compositions found in all samples (1629 stoichiometries) (shown in the right panel of each triad of the VK diagrams), as well as the subspace of unique CHO (highlighted in blue) and CHON (highlighted in red) compositions, which were seen in no more than two samples (shown in the left panel of each triad of the VK diagrams in Fig. 8).

The mentioned above common compositions found in all DOM samples used in this study were dominated by highly oxidized alicyclic and aromatic compounds such as carboxyl-rich alicyclic moieties (CRAM $)^{68}$, hydrolyzable and condensed tannins. Such a composition is indicative of highly oxidized character of DOM in the lower flow of the Ob-Irtysh river system, which is very different from the Kolyma River, where we have observed high contribution of less-oxidized, more saturated, and less-transformed organic matter ${ }^{65,69}$. These differences can be connected to much less significant contribution of the permafrost thaw into molecular composition of the Ob-Irtysh DOM as compared to the Kolyma River, whose basin is underlain by continuous permafrost ${ }^{70}$. The unique compositions (observed in less than two DOM samples under study), were characterized with much 

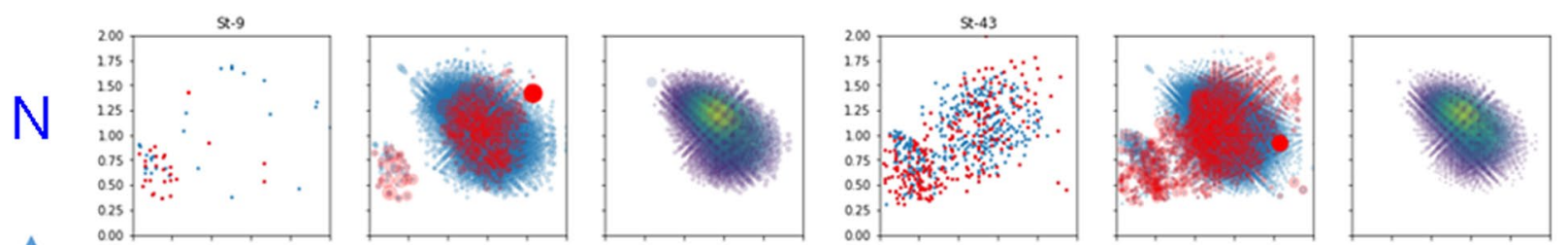

$\mathrm{N}$
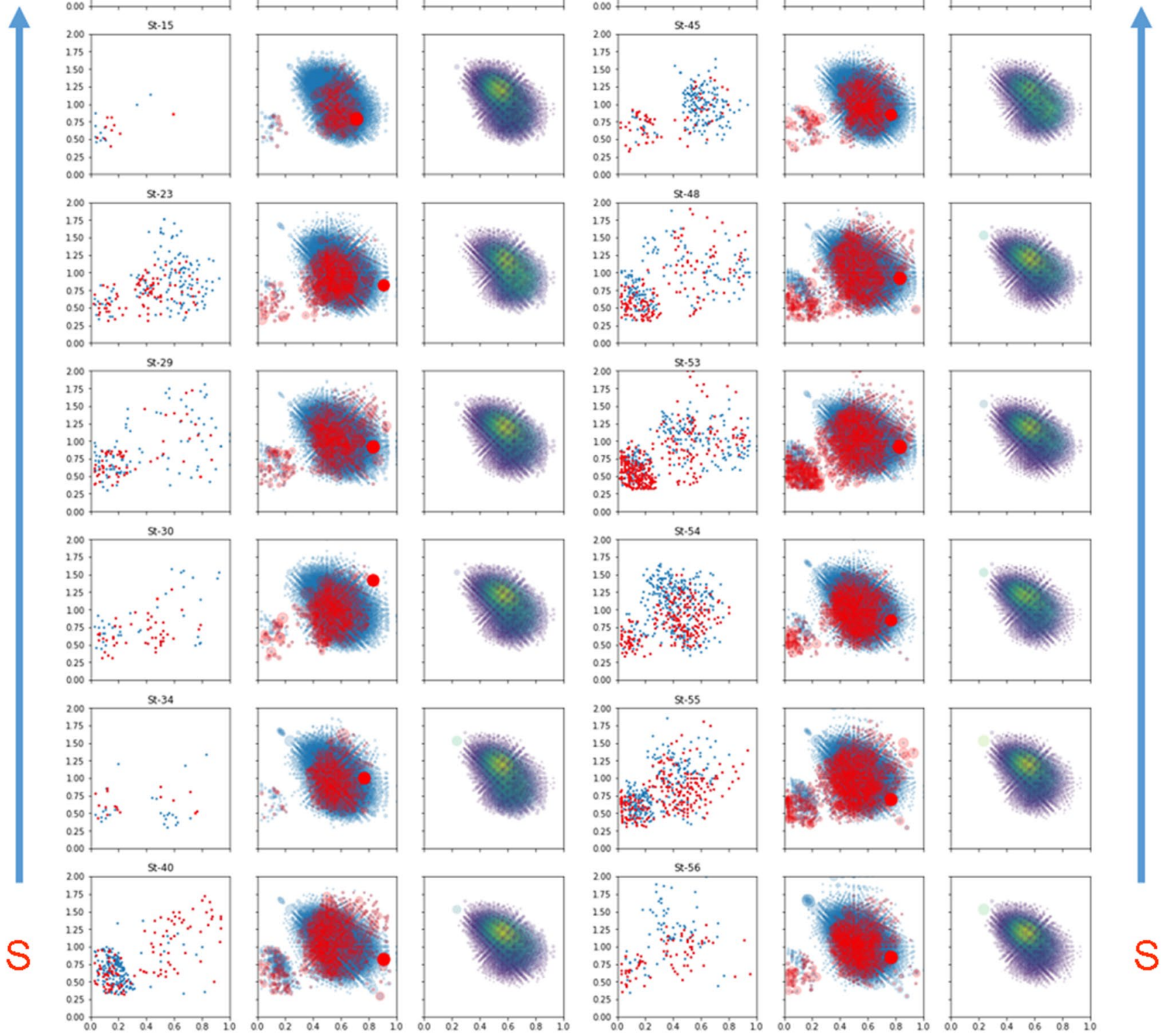

Figure 8. Three subspaces of Van Krevelen diagrams of the DOM samples collected along the South-North transect of the Ob-Irtysh river system. The samples are arranged in two columns. In each column, the central subspace is Van Krevelen diagram with $\mathrm{CHO}$ and $\mathrm{CHON}$ formulae highlighted in blue and red, respectively. The common for all samples formulae are shown in the right subpanels: they consist of 1629 stoichiometries. The unique formulae are shown in the left subpanels as $\mathrm{CHO}$ (in blue) and CHON (in red).

smaller intensities as compared to the common ones. Nevertheless, these formulae are indicative of the important trends in molecular transformations of DOM.

The clear differences in molecular compositions of the samples collected in the middle flow of the Ob River with the high impact of Vasyugan Mire (from St. 56 up to St. 40) can be seen in Fig. 8 (the right panels). They are characterized by multiple unique $\mathrm{CHO}$ compositions. These samples are characterized by distinct contribution of lignin compartments, which can be seen as blue dots with $\mathrm{H} / \mathrm{C}>1$ and $\mathrm{O} / \mathrm{C}<0.5$. The same samples are characterized with a remarkable imprint of aminosugars (CHON compounds) with $\mathrm{H} / \mathrm{C}>1$ and $\mathrm{O} / \mathrm{C}>0.7$. These molecular imprints might be indicative of high input of relatively fresh, low-degraded DOM from the Vasyugan mire to the middle stream of the Ob River. This can be also indicative of the input of fresh autochthonous organic matter in the South ${ }^{23}$ along with the major contribution of the "swamp" DOM. These imprints almost completely 


\begin{tabular}{|c|c|c|c|c|c|c|c|}
\hline \multirow{2}{*}{$\begin{array}{l}\text { DOM } \\
\text { sample }\end{array}$} & Aliphatics & Peptides, & $\begin{array}{l}\text { Low-oxidized } \\
\text { lignin }\end{array}$ & $\begin{array}{l}\text { Oxidized } \\
\text { lignin }\end{array}$ & $\begin{array}{l}\text { Condensed } \\
\text { tannins }\end{array}$ & $\begin{array}{l}\text { Hydrolyzable } \\
\text { tannins }\end{array}$ & Sugars \\
\hline & 1 & 2 & 3 & 4 & 5 & 6 & 7 \\
\hline St-1 & 0.012 & 0.039 & 0.237 & 0.386 & 0.012 & 0.293 & 0.021 \\
\hline St-3 & 0.101 & 0.033 & 0.188 & 0.353 & 0.012 & 0.296 & 0.015 \\
\hline St-9 & 0.006 & 0.028 & 0.221 & 0.401 & 0.008 & 0.314 & 0.021 \\
\hline St-12 & 0.002 & 0.007 & 0.200 & 0.377 & 0.008 & 0.396 & 0.010 \\
\hline St-15 & 0.004 & 0.015 & 0.236 & 0.449 & 0.007 & 0.278 & 0.011 \\
\hline St-20 & 0.008 & 0.067 & 0.187 & 0.411 & 0.015 & 0.266 & 0.045 \\
\hline St-23 & 0.000 & 0.000 & 0.114 & 0.419 & 0.010 & 0.445 & 0.012 \\
\hline St-29 & 0.005 & 0.039 & 0.204 & 0.399 & 0.009 & 0.320 & 0.024 \\
\hline $\begin{array}{l}\text { St-30 } \\
\text { (the } \\
\text { Irtysh) }\end{array}$ & 0.005 & 0.028 & 0.199 & 0.412 & 0.007 & 0.325 & 0.023 \\
\hline St-34 & 0.005 & 0.024 & 0.223 & 0.415 & 0.012 & 0.307 & 0.013 \\
\hline St-35 & 0.007 & 0.039 & 0.258 & 0.418 & 0.010 & 0.252 & 0.017 \\
\hline St-40 & 0.004 & 0.049 & 0.245 & 0.392 & 0.021 & 0.269 & 0.018 \\
\hline St-43 & 0.006 & 0.051 & 0.258 & 0.406 & 0.008 & 0.252 & 0.019 \\
\hline St-45 & 0.002 & 0.028 & 0.175 & 0.434 & 0.006 & 0.337 & 0.017 \\
\hline St-48 & 0.005 & 0.051 & 0.225 & 0.381 & 0.014 & 0.304 & 0.021 \\
\hline St-53 & 0.004 & 0.053 & 0.224 & 0.389 & 0.032 & 0.281 & 0.018 \\
\hline St-54 & 0.006 & 0.045 & 0.279 & 0.411 & 0.013 & 0.235 & 0.012 \\
\hline St-55 & 0.006 & 0.050 & 0.270 & 0.409 & 0.025 & 0.226 & 0.014 \\
\hline St-56 & 0.017 & 0.060 & \begin{tabular}{|l|}
0.277 \\
\end{tabular} & 0.422 & 0.009 & 0.198 & 0.016 \\
\hline
\end{tabular}

Table 3. Intensity-weighted population density of the Van Krevelen diagrams segregated into seven compound classes.

disappear after the Ob River receives a huge inflow of the Irtysh River waters (St. 30). From the confluence with the Irtysh River and further North, the CHO compositions become predominantly oxidized, dominated by oxidized polyphenols (tannins) and CRAMs, whereas CHON compounds are represented mostly by heterocyclic nitrogen-containing species. As a result, the Ob-Irtysh river system discharges into the $\mathrm{Ob}$ Bay relatively oxidized aromatic-rich DOM represented by the pool of common components shown in Fig. 8. The drastic differences in the DOM composition before and after the confluence of the Ob River with Irtysh can be clearly seen in Table 3.

Table 3 gives quantitative assessment of the molecular components present in the DOM, calculated as a population density of the respective regions in the Van Krevelen diagram, nominally: lipids, peptides, lignins, condensed tannins, hydrolyzable tannins, and sugars. It can be seen that the population density of peptides and aminosugars (class 2) drops from 0.06 to 0 along the northbound transect of the $\mathrm{Ob}$ River and slightly increases up to 0.039 in the Ob Bay. The same is true for low-oxidized lignins: the population density drops from 0.277 to 0.114 , whereas the hydrolyzable tannins are increased from 0.198 up to 0.445 . These quantitative estimates are in sync with the qualitative trends in molecular dynamics of DOM discussed above and indicate prevalence of the oxidized components within DOM in the Irtysh River, which dominate the DOM of the Ob River along its further traverse to the North.

The observed changes are also a result of the long transit times of water of the Ob River itself, which is characterized by a flat topography.

Linking molecular composition of the DOM to hydrochemistry of the Ob-Irtysh river system. For revealing relationships between hydrochemistry parameters and molecular composition of DOM, the approach described in detail by Kellerman et al. (2014) was used ${ }^{57}$. It implies calculation of the Spearman correlation coefficient $R$ between the relative abundance of 1629 common formulae (found in all DOM samples) and the values of hydrochemistry parameters shown in Table 1 . If more than 200 significant $(p<0.05)$ correlations were observed with the formulae abundance and the hydrochemistry parameter, the $R$ values for this parameter were highlighted with red (positive values) or blue (negative values) colors in the Van Krevelen diagram of the common formulae (Fig. 9).

The observed trends in molecular compositions of DOM enabled us to deduce that the significant correlation with hydrochemistry might be connected to the changes in contribution of the relatively reduced $(\mathrm{H} / \mathrm{C}>1)$ and low-oxidized compounds $(\mathrm{O} / \mathrm{C}<0.5)$ of ligninic nature versus condensed $(\mathrm{H} / \mathrm{C}<1)$ and highly oxidized $(\mathrm{O} / \mathrm{C}>0.5)$ species of hydrolyzable tannins. A value of $\mathrm{pH}$ is inversely correlated to the abundance of acidic hydrolyzable tannins and directly correlated to phenolic ligninic components, which agrees well with protolytic properties of these classes of compounds. However, the major contribution to $\mathrm{pH}$ value is provided by the carbonate system of the river. The same trends are characteristic for the other components of carbonate system $\left(\mathrm{HCO}_{3}{ }^{-}\right.$and $\left.\mathrm{CO}_{3}{ }^{2-}\right)$, which contribute the most into the alkalinity values of the natural water.

The correlation matrix for all hydrochemistry parameters is shown in Fig. S4. One can notice that the parameters exhibiting $>200$ significant correlations with the molecular compositions of DOM (shown in Fig. 9) are strongly correlated $(R>0.7)$. It looks like all parameters are governed by a change in the content of $C_{\text {org }}$ over the 

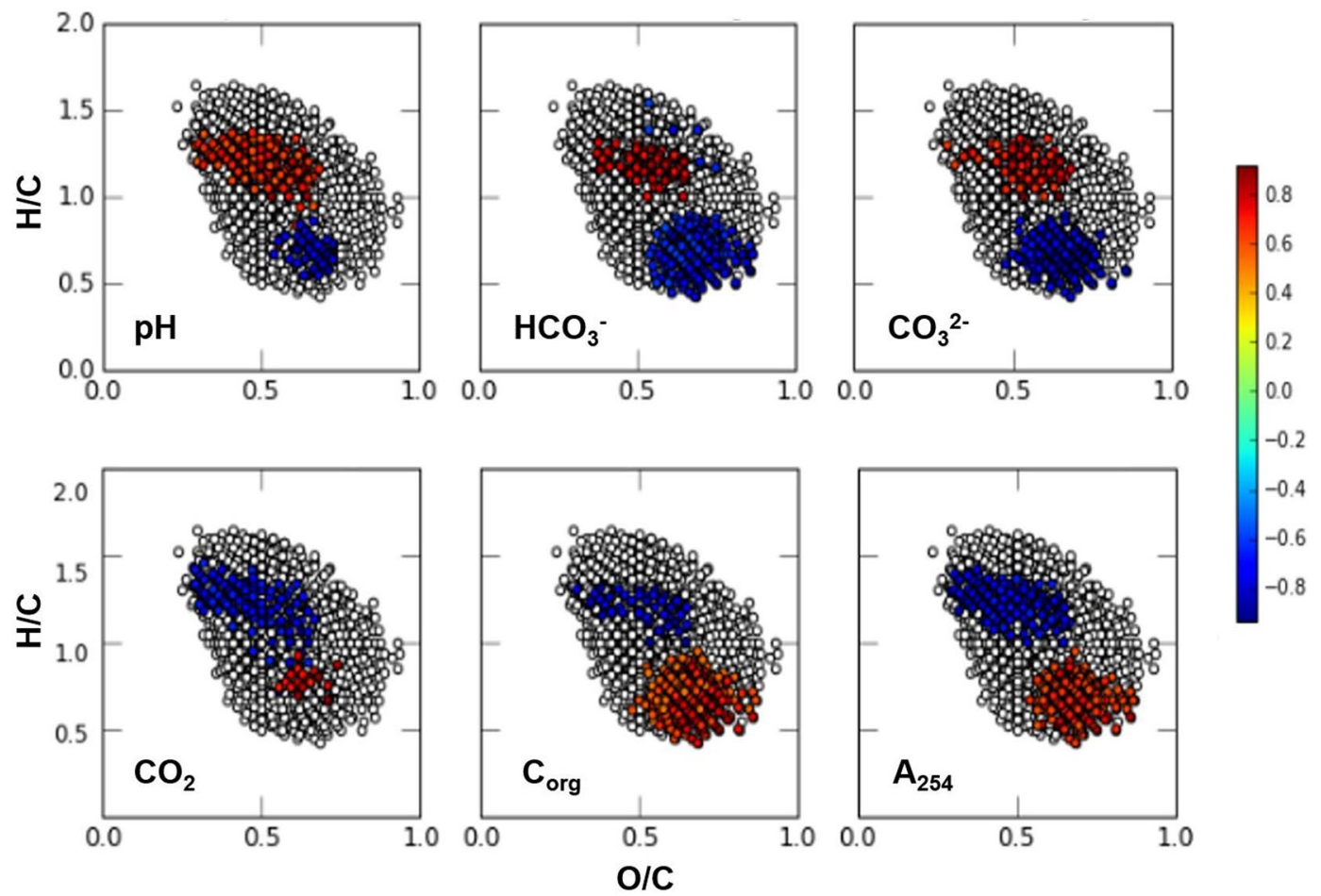

Figure 9. Correlation coefficients between hydrochemistry parameters and relative abundances of the common formulae, which were present in all samples, plotted in the Van Krevelen diagrams (the parameters exhibiting $>200$ significant correlations are considered as strongly correlated and highlighted in red $(R>0.7)$ of blue $((R<-0.7)$. The number of samples used for correlation analysis was 18 .

sampling stations (Fig. 1), which shows a dramatic increase from $0.2 \mathrm{mM} \cdot \mathrm{L}^{-1}$ near the Tom' confluence up to $1.1 \mathrm{mM} \cdot \mathrm{L}^{-1}$ after the Irtysh confluence, and remains almost the same $\left(0.9 \mathrm{mM} \cdot \mathrm{L}^{-1}\right)$ northbound to the Ob Bay. The content of $\mathrm{C}_{\text {org }}$ shows direct correlation with the abundance of tanninic species and inverse correlation - with the content of low-oxidized, reduced ligninic species. Given the origin of this drastic increase in the content of $\mathrm{C}_{\text {org }}$, the observed trend might be connected with a substantial difference in the molecular composition of DOM in the Irtysh as compared to the Ob. It is a reasonable suggestion given that the Irtysh River - the chief tributary of the Ob River is $4280 \mathrm{~km}$ long, it takes an origin in China and flows through semideserts of Kazakhstan and through the South Russia. The data allow us to surmise that the different climatic-geographic conditions (much higher temperatures and insolation) in the Irtysh basin might contribute to formation of more oxidized DOM in the Irtysh River as compared to DOM in the Ob River, which is dominated by the runoffs of the West Siberian swamps, e.g. the Great Vasyugan mire. Indeed, the number-averaged $(\mathrm{O} / \mathrm{C})_{n}$ ratios found in our studies (Table 2) exceeded 0.5, whereas the corresponding values for the permafrost-impacted Lena Delta ${ }^{37}$ were slightly above 0.4. In addition, $(\mathrm{H} / \mathrm{C})_{\mathrm{n}}$ values were significantly higher for the Lena Delta DOM $\left((\mathrm{H} / \mathrm{C})_{\mathrm{n}} \sim 1.2\right)$ as compared to the $(\mathrm{H} / \mathrm{C})_{\mathrm{n}}$ values of 1 found in our study. This is indicative of nuch more oxidized character of the Ob-Irtysh DOM, which is discharged through the Kara Sea into the Arctic Ocean. Hence, our data witness the dominating role of the Irtysh waters in a dramatic change in the quantity and quality of $\mathrm{C}_{\text {org }}$ discharged by the Ob River into the Arctic Ocean.

\section{Conclusions}

Application of FTICR MS and optical spectroscopy for molecular analysis of DOM sampled along the South-North transect of the Ob-Irtysh river system showed qualitative and quantitative trends in its molecular composition. The high resolution mass spectrometry discovered both biolabile and conservative components in the DOM samples used in this study. The biolabile components were related to aminosugars and reduced lignins: the degradation of aminosugars was reflected in the decreasing contribution of CHON components, whereas oxidation of lignins yielded an increase in the more stable oxidized phenolic compounds. A use of fluorescence spectroscopy confirmed the detected trends: it manifested gradual disappearance of the protein components and a decrease in the ratio of humic and oxidized phenolic fluorophores. Of importance is that the most intense and substantial changes in molecular character of DOM took place after the coalescence of the Ob River with its chief tributary - the Irtysh River indicating substantial difference in molecular composition of the DOM in Irtysh River, which caused the drastic change in the Ob River DOM. It can be also additionally impacted by the long travel times of the Ob River water due to the overall flat topography of the area ${ }^{63}$. The major characteristic feature of the "Irtysh-Ob" DOM is much higher content of polyphenolic species (hydrolyzable tannins) as compared to the "pre-Irtysh" DOM of the Ob River, which was dominated by the runoffs of the West Siberian swamps (e.g., Vasyugan Mire) and autotrophic water of tributaries (such as the Tom' River). The observed trends in 
molecular features of the Ob-Irtysh NOM are very different from those characteristic to aliphatics-rich bioavailable permafrost-dominated NOM. They witness much more conservative nature of the NOM discharged into the Arctic by the Ob-Irtysh river system. In general, the drastic reduction in molecular diversity of NOM on the path towards discharge into the Arctic Ocean observed in this study is consistent with the concept of decreased diversity of the universal components of NOM set forth by Zark and Dittmar ${ }^{71}$. It might result from the common synthetic pathways - microbial and UV degradation unifying the molecular constitution of the produced conservative NOM. These processes might be much more intense in the Irtysh River crossing much warmer climatic zones with higher insolation as compared to the upper and middle flow of the Ob River.

Received: 16 August 2019; Accepted: 28 November 2019;

Published online: 20 December 2019

\section{References}

1. Schuur, E. A. G. et al. Climate change and the permafrost carbon feedback. Nature 250, 171-179, https://doi.org/10.1038/ nature14338 (2015)

2. Hugelius, G. et al. Estimated stocks of circumpolar permafrost carbon with quantified uncertainty ranges and identified data gaps. Biogeosciences 11, 6573-6593 (2014).

3. Cole, J. J. et al. Plumbing the global carbon cycle: Integrating Inland Waters into the Terrestrial Carbon Budget. Ecosystems 10, 171-184 (2007).

4. Battin, T. J. et al. Biophysical controls on organic carbon fluxes in fluvial networks. Nat. Geosci. 1, 95-100 (2009).

5. Battin, T. J. et al. The boundless carbon cycle. Nat. Geosci. 2, 598-600 (2009).

6. Frey, K. E., Sobczak, W. V., Mann, P. J. \& Holmes, R. M. Optical properties and bioavailability of dissolved organic matter along a flow-path continuum from soil pore waters to the Kolyma River mainstream, East Siberia. Biogeosciences 13, 2279-2290 (2016).

7. Semiletov, I. P. On aquatic sources and sinks of $\mathrm{CO}_{2}$ and $\mathrm{CH}_{4}$ in the Polar Regions. J. Atmos. Sci. 56, 286-306 (1999).

8. Semiletov, I. P. et al. Atmospheric carbon emission from North Asian lakes: A factor of global significance. Atmos. Environ. 30, 1657-1671 (1996).

9. Semiletov, I. P. et al. Carbon transport by the Lena River from its headwaters to the Arctic Ocean, with emphasis on fluvial input of terrestrial particulate organic carbon vs. carbon transport by coastal erosion. Biogeosciences 8, 2407-2426 (2011).

10. Frey, K. E. \& Smith, L. C. Amplified carbon release from vast West Siberian peatlands by 2100. Geophys. Res. Lett. 32, L09401, https:// doi.org/10.1029/2004GL022025 (2005).

11. Frey, K. E. \& McClelland, J. W. Impacts of permafrost degradation on arctic river biogeochemistry. Hydrol. Process. 23, 169-182 (2009).

12. Gustafsson, Ö., van Dongen, B. E., Vonk, J. E., Dudarev, O. V. \& Semiletov, I. P. Widespread release of old carbon across the Siberian Arctic echoed by its large rivers. Biogeosciences 8, 1737-1743 (2011).

13. Raymond, P. A. et al. Flux and age of dissolved organic carbon exported to the Arctic Ocean: A carbon isotopic study of the five largest Arctic rivers. Global Biogeochem. Cycles 21, GB4011, https://doi.org/10.1029/2007GB002934 (2007).

14. Striegl, R. G., Dornblaser, M. M., McDonald, C. P., Rover, J. R. \& Stets, E. G. Carbon dioxide and methane emissions from the Yukon River system. Global Biogeochem. Cycles 26, GB0E05, https://doi.org/10.1029/2012GB004306 (2012).

15. Broder, L., Tesi, T., Andersson, A., Semiletov, I. \& Gustafsson, Ö. Bounding cross-shelf transport time and degradation in SiberianArctic land-ocean carbon transfer. Nat. Commun. 9, 806, https://doi.org/10.1038/s41467-018-03192-1 (2018).

16. Crawford, J. T., Striegl, R. G., Wickland, K. P., Dornblaser, M. M. \& Stanley, E. H. Emissions of carbon dioxide and methane from a headwater stream network of interior Alaska. J. Geophys. Res. Biogeosci. 118, 482-494, https://doi.org/10.1002/jgrg.20034 (2013).

17. Vonk, J. E. et al. Activation of old carbon by erosion of coastal and subsea permafrost in Arctic Siberia. Nature 489, 137-140 (2012).

18. Vonk, J. E. et al. Preferential burial of permafrost-derived organic carbon in Siberian-Arctic shelf waters. J. Geophys. Res. Ocean 119, 8410-8421 (2014).

19. Vonk, J. E. et al. Distinguishing between old and modern permafrost sources in the northeast Siberian land-shelf system with compound-specific $\delta^{2} \mathrm{H}$ analysis. Cryosphere 11, 1879-1895 (2017).

20. Hayes, D. et al. The impacts of recent permafrost thaw on land-atmosphere greenhouse gas exchange. Environ. Res. Lett. 9, 045005 (2014).

21. Karlsson, E. S. et al. Contrasting regimes for organic matter degradation in the East Siberian Sea and the Laptev Sea assessed through microbial incubations and molecular markers. Marine Chemistry 170, 11-22 (2015).

22. Pipko, I. I., Pugach, S. P., Dudarev, O. V., Charkin, A. N. \& Semiletov, I. P. Carbonate parameters of the Lena River: characteristics and distribution. Geochem. Intern. 48, 1131-1137 (2010).

23. Pipko, I. I. et al. Dynamics of dissolved inorganic carbon and $\mathrm{CO}_{2}$ fluxes between water and atmosphere in the main channel of the Ob River. Doklady Chemistry 484, 52-57 (2019).

24. Spencer, R. G. M. et al. Detecting the signature of permafrost thaw in Arctic rivers. Geophys. Res. Lett. 42, 2830-2835, https://doi. org/10.1002/2015GL063498 (2015).

25. Tesi, T. et al. Composition and fate of terrigenous organic matter along the Arctic land-ocean continuum in East Siberia: Insights from biomarkers and carbon isotopes. Geochim. Cosmochim. Acta 133, 235-256 (2014).

26. Tesi, T. et al. Massive remobilization of permafrost carbon during post-glacial warming. Nat. Commun. 7, 13653 (2016).

27. Holmes, R. M. et al. Seasonal and annual fluxes of nutrients and organic matter from large rivers to the Arctic Ocean and Surrounding Seas. Estuaries Coasts 35, 369-382 (2012).

28. Eckstein, Y., Savichev, O. G. \& Pasechnik, E. Yu. Two decades of trends in ground water chemical composition in The Great Vasyugan Mire, Western Siberia, Russia. Environ Earth Sci. 73, 7329-7341, https://doi.org/10.1007/s12665-014-3908-z (2015).

29. Inisheva, L. I. \& Maslov, B. S. The mysterious world of mires. 225 [in Russian] (Tomsk State Pedagogical University Press, 2013).

30. Sheng, Y. et al. A high-resolution GIS-based inventory of the west Siberian peat carbon pool. Global Biogeochem. Cycles 18, GB3004, https://doi.org/10.1029/2003GB002190(2004).

31. Gordeev, V. V., Rachold, V. \& Vlasova, I. E. Geochemical behaviour of major and trace elements insuspended particulate material of the Irtysh river, the main tributary of the Ob river, Siberia. Applied Geochemistry 19, 593-610 (2004).

32. Surface Water Resources of the USSR, vol. 15; Altai and Western Siberia; issue 2: Middle Ob, (ed. Panina, N. A.) [in Russian] (Gidrometeoizdat, 1972).

33. Thurman, E. M. Aquatic humic substances: Org. Geochemistry Nat. Waters 273-361 (Springer, 1985).

34. Marshall, A. G., Hendrickson, C. L. \& Jackson, G. S. Fourier transform ion cyclotron resonance mass spectrometry: A primer. Mass Spectrom. Rev. 17, 1-35 (1998).

35. Hertkorn, N. et al. Natural organic matter and the event horizon of mass spectrometry. Anal. Chem. 80, 8908-8919 (2008).

36. Stubbins, A. et al. Illuminated darkness: Molecular signatures of Congo River dissolved organic matter and its photochemical alteration as revealed by ultrahigh precision mass spectrometry. Limnol. Oceanogr. 55, 1467-1477 (2010). 
37. Dubinenkov, I., Flerus, R., Schmitt-Kopplin, P., Kattner, G. \& Koch, B. Origin-specific molecular signatures of dissolved organic matter in the Lena Delta. Biogeochemistry 123, 1-14, https://doi.org/10.1007/s10533-014-0049-0 (2015).

38. Walker, S. A., Amon, R. M. W. \& Stedmon, C. A. Variations in high-latitude riverine fluorescent dissolved organic matter: A comparison of large Arctic rivers. J. Geophys. Res. Biogeosci. 118, 1689-1702, https://doi.org/10.1002/2013JG002320 (2013).

39. Drake, T. W. et al. The ephemeral signature of permafrost carbon in an Arctic fluvial network. Journal of Geophysical Research: Biogeosciences 123, 1475-1485, https://doi.org/10.1029/2017JG004311 (2018).

40. Kaiser, K., Benner, R. \& Amon, R. M. W. The fate of terrigenous dissolved organic carbon on the Eurasian shelves and export to the North Atlantic. J. Geophys. Res. Oceans 122, 4-22, https://doi.org/10.1002/2016JC012380 (2017).

41. Frey, K. E., Siegel, D. I. \& Smith, L. C. Geochemistry of west Siberian streams and their potential response to permafrost degradation. Water Resour. Res. 43, W03406 (2007)

42. Loiko, S. V. et al. Abrupt permafrost collapse enhances organic carbon, $\mathrm{CO}_{2}$, nutrient and metal release into surface waters. Chemical Geology 471, 153-165 (2017).

43. Stunzhas, P. A. \& Makkaveev, P. N. Volume of the Ob Bay waters as a factor of the formation of the hydrochemical inhomogeneity. Oceanology 54, 583-595 (2014).

44. Pokrovsky, O. S. et al. Permafrost coverage, watershed area and season control of dissolved carbon and major elements in western Siberian rivers. Biogeosciences 12, 6301-6320, https://doi.org/10.5194/bg-12-6301-2015 (2015).

45. Alling, V. et al. Nonconservative behavior of dissolved organic carbon across the Laptev and East Siberian seas. Glob. Biogeochem. Cycles 24, GB4033 (2010).

46. Sharp, J. H. et al. Analyses of dissolved organic carbon in seawater: the JGOFS EqPac. methods comparison. Mar. Chem. 48, 91-108 (1995).

47. Dickson, A. G. \& Goyet, C. (eds) Handbook of Methods for the Analysis of the Various Parameters of the Carbon Dioxide System in Seawater Version 2, ORNL/CDIAC-74 (DOE, 1994).

48. Bruevich, S. V. Instruction for Chemical Investigation of Seawater [in Russian] (Glavsevmorput, 1944).

49. Pavlova, G. Y., Tishchenko, P. Y., Volkova, T. I., Dickson, A. \& Wallmann, K. Intercalibration of Bruevich's method to determine the total alkalinity in seawater. Oceanologiya 48, 23-32 (2008).

50. Blough, N. V. \& Del Vecchio, R. Chromophoric DOM in the coastal environment in Biogeochemistry of Marine Dissolved Organic Matter (eds. Hansell, D. A. \& Carlson, C. A.) 509-546 (Elsevier, San Diego, California, 2002).

51. Lewis, E. \&Wallace, D.W. R. Program Developed for $\mathrm{CO}_{2}$ System Calculations ORNL/CDIAC-105 (Carbon Dioxide Information Analysis Center, Oak Ridge National Laboratory, 1998).

52. Pipko, I. I. et al. The spatial and interannual dynamics of the surface water carbonate system and air-sea $\mathrm{CO}_{2}$ fluxes in the outer shelf and slope of the Eurasian Arctic Ocean. Ocean Science 13, 997-1016 (2017).

53. Pugach, S. P. et al. Dissolved organic matter and its optical characteristics in the Laptev and East Siberian seas: spatial distribution and interannual variability (2003-2011). Ocean Science 14, 87-103 (2018).

54. Semiletov, I. et al. Acidification of East Siberian Arctic Shelf waters through addition of freshwater and terrestrial carbon. Nat. Geosci. 9, 361-365 (2016).

55. Dittmar, T., Koch, B., Hertkorn, N. \& Kattner, G. A simple and efficient method for the solid-phase extraction of dissolved organic matter (SPE-DOM) from seawater. Limnol. Ocean. Methods. 6, 230-235 (2008).

56. Kunenkov, E. V. et al. Total Mass Difference Statistics Algorithm: A New Approach to Identification of High-Mass Building Blocks in Electrospray Ionization Fourier Transform Ion Cyclotron Mass Spectrometry Data of Natural Organic Matter. Anal. Chem. 81, 10106-10115 (2009).

57. Kellerman, A. M., Dittmar, T., Kothawala, D. N. \& Tranvik, L. J. Chemodiversity of dissolved organic matter in lakes driven by climate and hydrology. Nat. Commun. 5, 3804 (2014).

58. Perminova, I. V. From green chemistry and nature-like technologies towards ecoadaptive chemistry and technology. Pure and Applied Chemistry 91, 851-864 (2019)

59. Helms, J. R. et al. Absorption spectral slopes and slope ratios as indicators of molecular weight, source, and photobleaching of chromophoric dissolved organic matter. Limnology and Oceanography 53, 955-969 (2008).

60. Murphy, K. R., Stedmon, C. A., Graeber, D. \& Bro, R. Fluorescence spectroscopy and multi-way techniques. PARAFAC. Analytical Methods 5, 6557-6566 (2013).

61. Perminova, I. V. et al. The Structural Arrangement and Relative Abundance of Aliphatic Units May Effect Long-Wave Absorbance of Natural Organic Matter as Revealed by ${ }^{1} \mathrm{H}$ NMR Spectroscopy. Environ. Sci. Technol. 52, 12526-12537 (2018).

62. Pucher, M., Graeber, D. staRdom: PARAFAC analysis on DOM EEMs, calculating absorbance slopes (2019). https://github.com/ MatthiasPucher/staRdom.

63. Dickens, A. F., Baldock, J., Kennad, T. C. \& Eglinton, T. I. A depositional history of particulate organic carbon in a floodplain lake from the lower Ob’ River, Siberia. Geochim. Cosmochim. Acta 75, 4796-4815 (2011).

64. Wuensch, U. et al. The molecular fingerprint of fluorescent Natural Organic Matter offers insight into biogeochemical sources and diagenetic state. Anal. Chem. 90, 14188-14198 (2018).

65. Sleighter, R. L., Liu, Z., Xue, J. \& Hatcher, P. G. Multivariate statistical approaches for the characterization of dissolved organic matter analyzed by ultrahigh resolution mass spectrometry. Environ. Sci. Technol. 44, 7576-7582 (2010).

66. Kim, S., Kramer, R. W. \& Hatcher, P. G. Graphical method for analysis of ultrahigh-resolution broadband mass spectra of natural organic matter, the Van Krevelen diagram. Anal. Chem. 75, 5336-5344 (2003).

67. Waggoner, D. C., Wozniak, A. S., Cory, R. M. \& Hatcher, P. G. The role of reactive oxygen species in the degradation of lignin derived dissolved organic matter. Geochim. Cosmochim. Acta 208, 171-184, https://doi.org/10.1016/j.gca.2017.03.036 (2017).

68. Hertkorn, N. et al. Characterization of a Major Refractory Component of Marine Dissolved Organic Matter. Geochim. Cosmochim. Acta 70, 2990-3010 (2006).

69. Perminova, I. V. et al. Molecular mapping of sorbent selectivities with respect to isolation of arctic dissolved organic matter as measured by Fourier transform mass spectrometry. Environ. Sci. Technol. 48, 7461-7468 (2014).

70. Vonk, J. E. et al. Dissolved organic carbon loss from Yedoma permafrost amplified by ice wedge thaw. Environ. Res. Lett. 8, 035023 (2013).

71. Zark, M. \& Dittmar, T. Universal molecular structures in natural dissolved organic matter. Nat. Comm. 9, 3178, https://doi. org/10.1038/s41467-018-05665-9 (2018).

72. Wessel, P., Smith, W. H. F., Scharroo, R., Luis, J. \& Wobbe, F. Generic Mapping Tools: Improved Version Released. EOS Trans. AGU 94(45), 409-410, https://doi.org/10.1002/2013EO450001 (2013).

\section{Acknowledgements}

This work was supported by the Russian Scientific Foundation: grant \# 15-17-20032 (N.S. and O.D.) conceptualization of the research plan and organization of the expedition, the Russian Foundation for Basic Research: grants \# 18-29-25065 (IVP), 18-32-20116 (E.S.), 18-05-70047 (O.D.), 17-05-00148 (O.D.), 18-05-00559 (IIP), and the Russian government: \#14, Z50.31.0012/03.19.2014 (IS, IIP, SP). 


\section{Author contributions}

I.P. - conceptualization of paper, data interpretation, writing paper. E.S. - optical data acquisition and treatment, writing paper. A.Z. - FTICRMS data acquisition and treatment, writing paper. I.I.P. - hydrochemistry data acquisition and interpretation, writing paper. SP - hydrooptics data acquisition and interpretation. O.D. samples collection and DOM isolation. E.N. - FTICRMS experiments conceptualization, data discussion. A.G. - development of Transhumus software. N.S. - literature review, introduction writing. I.S. - organizer of the expedition, paper conceptualization.

\section{Competing interests}

The authors declare no competing interests.

\section{Additional information}

Supplementary information is available for this paper at https://doi.org/10.1038/s41598-019-55662-1.

Correspondence and requests for materials should be addressed to I.V.P.

Reprints and permissions information is available at www.nature.com/reprints.

Publisher's note Springer Nature remains neutral with regard to jurisdictional claims in published maps and institutional affiliations.

(1) Open Access This article is licensed under a Creative Commons Attribution 4.0 International License, which permits use, sharing, adaptation, distribution and reproduction in any medium or format, as long as you give appropriate credit to the original author(s) and the source, provide a link to the Creative Commons license, and indicate if changes were made. The images or other third party material in this article are included in the article's Creative Commons license, unless indicated otherwise in a credit line to the material. If material is not included in the article's Creative Commons license and your intended use is not permitted by statutory regulation or exceeds the permitted use, you will need to obtain permission directly from the copyright holder. To view a copy of this license, visit http://creativecommons.org/licenses/by/4.0/.

(C) The Author(s) 2019 